\title{
REVISITANDO LOS DESIERTOS: NACIÓN, TERRITORIO E IDENTIDAD EN UN VIAJE AL CHACO (1872)
}

\author{
Deserts revisited: nation, territory and identity in a trip to the Chaco (1872)
}

\section{Beatriz Vitar*}

\section{Resumen}

En este trabajo se analiza la construcción de la imagen de un territorio en el marco del proceso de formación nacional en Argentina y del fomento de la inmigración y colonización europea como vía para el dominio efectivo de las zonas indígenas aun no sometidas al control del Estado. En una coyuntura de expansión capitalista, orientada a la explotación de los recursos naturales dentro del modelo económico agro-exportador, fue clave la disponibilidad de vías interiores de comunicación, terrestres y fluviales. En este contexto se realizaron en la segunda mitad del siglo XIX una serie de viajes de exploración al Chaco, entre los que se encuentra la expedición por el río Bermejo en 1872 con el fin de estudiar su navegabilidad, dando origen al relato en el que se basa este estudio. El análisis de esta obra permite constatar el papel de la narrativa de viajes como legitimadora del proyecto estatal de consolidación territorial, bajo el lema de civilización y progreso y, asimismo, discernir el fenómeno de (re)elaboración de identidades en un espacio de múltiples confluencias étnicas a través de una estrategia discursiva cuyo fin es justificar la superioridad europea en los planes de colonización del Chaco con inmigrantes de ese origen, nuevos agentes civilizadores que sacarían a los indígenas de su primitivismo convirtiéndolos en sujetos productivos.

$$
<\text { Chaco }><\text { Viajes exploratorios }><\text { Territorio }><\text { Identidades }>
$$

\begin{abstract}
This paper examines the construction of the image of a territory within the framework of the process of national formation in Argentina, and the promotion of the immigration and European colonization in order to achieve the effective domain of indigenous areas not yet under the control of the State. At a juncture of capitalist expansion, aimed to the exploitation of the natural resources within the agro economic model, the availability of internal communication, land and river routes was crucial. In this context, a series of trips of exploration to the Chaco were performed in the second half of the 19th century, among which the expedition by the Bermejo River in 1872 to study its seaworthiness, lead to the story in which this study is based. The analysis of this work allows to verify the role of travel narrative as legitimizing of the State project of territorial consolidation, under the banner of civilization and progress. Besides, it permits to discern to discern the phenomenon of (re) defining identities in a space of multiple ethnic junctions. This is achieved through a discursive strategy which aims to justify the European superiority in the colonization of the Chaco plans with immigrants from that origin. These inmigrants were conceived as as new civilizing agents who would convert the primitive Indians into productive subjects.
\end{abstract}

$<$ Chaco $><$ Exploratory travels $><$ Territory $><$ Identities $>$

Recibido: 01/07/2016 // Aceptado: 03/09/2016

* Doctora en Historia de América. UCM-US. mvitar@us.es 


\section{Introducción}

En el siglo XIX, y en especial en la segunda mitad de esta centuria, la fiebre viajera se expandió por las zonas del territorio argentino que permanecían al margen del mundo civilizado, como el Chaco y la Patagonia. Bajo el aliento de una política orientada a la consolidación del Estado nacional y en el marco de un capitalismo en expansión se puso en marcha un conjunto de estrategias para incorporar esos --así llamados-- desiertos al ritmo de la modernidad tal como era concebida por los sectores dirigentes, erradicando la barbarie. En este proceso los viajes exploratorios realizados tanto por nacionales como por extranjeros tuvieron un papel clave a través de una prolífica narrativa (memorias, informes, relatos o diarios, entre otros), que sirvió de soporte a los objetivos de dominio territorial y sometimiento de los pueblos nativos en nombre del progreso.

En ese contexto se inscribe el viaje del que trataré aquí, que constituye un claro exponente del creciente interés por las potencialidades económicas de las regiones antes mencionadas, sirviendo de acicate a las exploraciones ejecutadas por representantes de compañías privadas, hombres de ciencias (naturalistas, ingenieros, geógrafos) o militares, empresas que contaron con el auspicio de los gobiernos criollos y/o su participación directa. De acuerdo con el modelo agro-exportador que marcó las pautas del desarrollo económico en Argentina y en otras naciones del continente, la disponibilidad de vías interiores de transporte se convirtió en un imperativo de primer orden; tan crucial como la red ferroviaria fue la disponibilidad de ríos navegables, en aras del desenvolvimiento productivo de vastas zonas donde el Estado aspiraba a una posesión plena y a explotar sus recursos a través de la inmigración y la colonización europea. Un claro ejemplo de esta política fue la exploración del río Bermejo en 1872 con el objetivo de estudiar la navegabilidad a lo largo de su curso, dando origen al relato Viajes por la República Argentina. Una expedición al Chaco, obra del español César Valcárcel (Madrid, 1883). ${ }^{1}$

Este relato, en el que el autor volcó su experiencia como capitán de las fuerzas terrestres que escoltaron al vapor Leguizamón en su travesía por el ríoº, puede ser enfocado desde diversos ángulos, sin duda merecedores de un trabajo de mayores dimensiones, aunque por razones de espacio me limitaré a presentar algunas reflexiones surgidas tras una primera aproximación al texto, centrándome en algunos de sus muchos aspectos dignos de estudio. Por una parte, abordaré el contexto histórico en el que se realizó la expedición de 1872 y la figura de uno de sus protagonistas y autor de la citada obra; por otra, me centraré en las características de la narración y su contenido, para tratar dos problemas relevantes: la elaboración de una imagen del territorio del Chaco como espacio virgen para ser explotado -esas "inmensas soledades" o "desiertos"-- a los que

\footnotetext{
1 Esta obra se encuentra disponible en la Biblioteca Digital Hispánica: http://bdh-rd.bne.es/viewer. $\mathrm{vm}$ ?id=0000039240\&page $=1$, siendo este ejemplar digitalizado el que he consultado y del que han sido extraídos los fragmentos textuales citados en este trabajo, cuyas referencias a los números de páginas se corresponden con las de la fuente original. Asimismo, he modernizado la grafía, aunque los ajustes han sido mínimos debido a que se trata de un texto del siglo XIX.

2 El recorrido del Leguizamón por el río Bermejo fue a su vez objeto de otras dos memorias: Castro Boedo (1873) y Aráoz (1886).
} 
sólo el poblamiento europeo podría sacar de su incivilidad, fiereza e improductividad, y la construcción de identidades en un escenario de múltiples confluencias étnicas. Con este fin enfocaré el análisis en los protagonistas centrales del relato: el propio autor, el francés Vernuil y su hija adoptiva, la mestiza Notaj/Diana, cuyos actos así como sus discursos auto-identitarios contienen los argumentos legitimadores de las políticas de dominio territorial y sujeción de los pueblos indígenas a los dictados de la civilización, representada por la inmigración europea. Dentro de este esquema, se rediseñó la condición ideal de los indígenas, cual era la de sujetos productivos. Si bien algunas de estas cuestiones han sido analizadas en importantes trabajos referidos a las regiones chaqueña y patagónica, el objeto de estas páginas es sumar una nueva aportación a la historiografía sobre los márgenes, aplicando otras perspectivas a su estudio en una coyuntura histórica crucial en la que se fue conformando el imaginario de una nación habitada por blancos: los herederos de los conquistadores hispanos y los procedentes de los flujos migratorios europeos, los ya asentados y los por venir.

\section{La expansión capitalista y la navegación de los ríos. La expedición al río Bermejo de 1872}

La exploración de 1872 intentó hacer realidad un viejo anhelo, el estudio de la navegación del río Bermejo, cuyos antecedentes se remontan a los tiempos coloniales tardíos. Sin embargo, a diferencia de los móviles que guiaron a los gobiernos criollos, los intentos realizados desde la provincia del Tucumán en el siglo XVIII obedecieron más al interés de la comunicación entre el Alto Perú y el Río de la Plata que a la incorporación del Chaco como "área productiva" dentro de la economía regional (Lagos y Santamaría, 2008: 7). Un primer paso fue la "entrada" del gobernador Joaquín de Espinosa y Dávalos en 1759, durante la cual se navegó el Bermejo hasta unas 40 leguas antes de llegar Corrientes, interrumpiéndose el avance debido a las numerosas lagunas formadas en ese punto. Más tarde, la expedición del gobernador Juan Manuel Campero, con el auxilio del jefe mocoví Colompotoc y de varios misioneros de la Compañía de Jesús (que aspiraba a conectar las zonas misioneras bajo su jurisdicción), también arrancó del Tucumán con el objetivo de reconocer la navegabilidad del Bermejo hasta el territorio correntino. Pero esta meta quedó malograda tras ordenarse suspender la navegación y dar prioridad a la sujeción de los guaycurúes no reducidos (Vitar, 1997: 206, 210-212), repitiéndose en lo que restaba del siglo XVIII una serie de exploraciones partiendo también del oeste hacia el Litoral. Ya en la época republicana, desde 1820 y hasta los años 1860 se sucedieron otros viajes con el mismo objetivo, sin resultados satisfactorios (Lagos y Santamaría, 2008: 3).

Desde mediados del siglo XIX, el Estado argentino trató de impulsar la colonización y el desarrollo productivo de los territorios que aún se hallaban fuera del control gubernamental --Chaco y Patagonia--, para lo cual era indispensable potenciar las vías de comunicación terrestre y fluvial. Con respecto a estas últimas, los principios enunciados por Juan B. Alberdi en sus Bases y puntos de partida... (1852) fueron adoptados con fervor por la clase dirigente y los sectores intelectuales y profesionales 
adheridos al dogma del progreso. Por ello, no es de extrañar que en los informes sobre los viajes exploratorios al Chaco, los preceptos alberdianos brillasen con luz propia en la defensa de la libre navegación de los ríos como uno de los pilares de la prosperidad de la nación. Así lo ilustran la portadilla de la memoria de Guillermo Aráoz sobre la expedición al Bermejo de 1872, que lleva inserto un fragmento de la carta que dirigiese Alberdi a aquel autor: "No conozco industria más bella y honorable entre nosotros que la que tiene por objeto el tráfico y las vías de comunicación” (Aráoz, 1883) y, también, la exhortación a quienes conducían los destinos del país con la frase "Las vías de navegación son instrumentos de gobierno", que encabeza el escrito del ingeniero Luis A. Huergo sobre la navegación interna en Argentina (Huergo, 1902: XI). Guiados por este espíritu los gobiernos apoyaron iniciativas privadas a fines de promover el transporte fluvial dentro del territorio. En lo que se refiere al Chaco, se trataba de habilitar la navegación de los ríos Bermejo y Salado, ambos de interés para el fomento de la colonización y la actividad productiva en la zona noroeste y noreste; con ello se allanaría la salida de productos a los mercados de consumo mediante un "tránsito rápido", como el que se operaba a través de las "arterias principales", los ríos Paraná, Uruguay y Paraguay (Rams Rubert y Riestra, 1860: 1). ${ }^{3}$ En concordancia con estos planes, los objetivos de la expedición de 1872, fueron lograr "la fácil y positiva navegación del Bermejo, el prolijo reconocimiento de las riquezas naturales del Chaco y sus mejores puntos para colonizar y la asequibilidad de las principales tolderías de los indios para someterse a una nueva y generosa civilización" (Castro Boedo, 1873: 121).

La exploración de 1872 tuvo sus orígenes en el contrato firmado por el gobierno de Domingo F. Sarmiento "con los señores Natalio Roldán y Matti” en 1869, con el fin de "verificar la navegación del río Bermejo hasta el punto de la Esquina Grande, explorando el canal del río hasta Orán o Lavallén- [e] introducir la navegación a vapor". En virtud de esta concesión se constituyó en 1870 la Compañía de Navegación a Vapor del Río Bermejo, que realizó al año siguiente una expedición de doce meses con el vapor Sol Argentino, a cargo del ingeniero inglés Thomas Page y del comerciante Natalio Roldán, como representante de la Compañía (Huergo, 1902: 66-67; Castro Boedo, 1873: 118). Los malos resultados de esta primera exploración motivaron al año siguiente un segundo viaje de navegación, también dirigido por Natalio Roldán, a quien acompañaron el entonces presbítero Emilio Castro Boedo, "cronista de la expedición" (Valcárcel, 1883: 13) y el "comisario" Guillermo Aráoz, al servicio de la Compañía de Roldán (Aráoz, 1886: 6). Esta expedición, que llegó a congregar no sólo a argentinos sino también a extranjeros de distinta procedencia avecindados en el país, partió del Riachuelo en mayo de 1872 y completó su recorrido hasta unas 20 leguas al sur de Orán, retornando a Buenos Aires en abril de 1873 (Aráoz, 1886: 52-53). Según los datos proporcionados por Castro Boedo, entre los 26 miembros de la tripulación se encontraban el "práctico" español Manuel Cabo de Vila, el uruguayo Juan Barbosa

3 El afán exploratorio no se circunscribió al Chaco sino que se extendió también a la zona patagónica, promoviendo las exploraciones y estudios del río Negro (Huergo, 1902: VI).

4 Asimismo, mediante el contrato firmado en 1869 el gobierno otorgó a los concesionarios tierras en propiedad y una subvención por cada viaje realizado por el río. Más detalles en Huergo (1902: 66-68). 
(segundo comisario), un maquinista inglés y dos "empleados" de Roldán: un hijo de Barbosa, y Miguel Raimundín, "español de conducta recomendable" (Castro Boedo, 1873: 120). A las órdenes de Roldán se hallaba nuestro cronista, César Valcárcel, en calidad de capitán de las fuerzas que, en prevención de ataques indígenas, escoltaron por tierra al vapor Leguizamón en su derrotero fluvial. E1 "pequeño" ejército de Valcárcel estuvo integrado por "cincuenta soldados elegidos", entre los cuales iban lenguaraces (conocedores de la lengua toba) y algunos "baqueanos" en el Chaco; otros miembros de la expedición terrestre fueron el teniente Sandoval ${ }^{5}$ ("segundo" de Valcárcel); el sargento Decker, de origen alemán; un "curandero italiano que se hacía llamar doctor" 6 y algunas mujeres de soldados, encargadas del servicio de "ambulancia" (Valcárcel, 1883: 10-11). Curiosamente, tanto en la crónica de Castro Boedo como en la de Aráoz, no existe ninguna referencia a Valcárcel ni al ejército bajo sus órdenes.

Con relación a las etapas del itinerario ${ }^{7}$, Valcárcel no aporta una relación clara y precisa, haciendo solo referencia a los lugares de acampada de su ejército en las cercanías de la laguna de los Correntinos y del arroyo de San Lorenzo, tributario del Bermejo, al paso por la isla de Nacurutú ${ }^{8}$ (Valcárcel, 1883: 10-11) y, desde este punto -intermediando un largo paréntesis para narrar diversos sucesos- a la llegada a las cercanías de Lacangayé (emplazamiento de la antigua misión San Bernardo) después de ocho días de marcha (Valcárcel, 1883: 12). Desde este punto Valcárcel se trasladó a Rivadavia (Salta), de donde continuó rumbo a la capital de esta provincia para luego regresar a Buenos Aires, culminando así su viaje.

En definitiva, la exploración de 1872 no dio los frutos esperados debido a las dificultades para la navegación del río, entre ellas su lecho arenoso, como lo destacaba Valcárcel (1883: 20), además de los problemas técnicos del vapor y de las inundaciones que "malograron" las obras de canalización (Aráoz, 1886: 52-53). No tuvieron mejor suerte las expediciones realizadas con posterioridad, llegándose a fines del siglo XIX sin haber superado los escollos con los que se enfrentaron los ensayos anteriores. Tras la fracasada tentativa del empresario inglés Leach en 1899, "el resultado final fue convencerse de la innavegabilidad del Bermejo" (Lagos y Santamaría, 2008: 9) pero, como señalan estos dos autores, no sólo "la naturaleza del río hizo su parte" sino también los intereses de las compañías ferroviarias, por la competencia que pudiera ofrecer el transporte fluvial (Lagos y Santamaría, 2008: 13-14). Como colofón a esos sueños de progreso y modernización, hoy quedan los restos de un "barco varado en el monte" en la localidad de Rivadavia (Salta), "expresión inmóvil de declinación y abandono" (Gordillo, 2015: 25-55).

\footnotetext{
5 Este "joven oficial argentino" era hijo del coronel Sandoval, "explorador del Chaco y jefe militar que había sido de aquellas fronteras" y de él Valcárcel (1883) apunta en nota al pie: "Fantaseado este personaje, cambiamos su nombre verdadero" (p. 40).

6 Más adelante, Valcárcel alude a este italiano como el "Dr. Remini".

7 Para una información detallada sobre los hitos de la exploración de 1872, véase Castro Boedo (1873) y Aráoz (1886).

8 En este punto del itinerario, la expedición de Valcárcel iba adelantada con respecto a la travesía por el río: "[...] andábamos siempre cuatro horas más que el vapor, que seguía los movimientos de los de tierra" (Valcárcel, 1883: 11).
} 


\section{El relato de César Valcárcel sobre su experiencia chaqueña}

En lo que se refiere a la trayectoria vital de este militar-viajero, casi todo son conjeturas, ya que no se dispone sino de las pocas referencias que brinda el propio relato de Una expedición al Chaco, más algunos indicios que ofrecen otras obras del mismo autor". Valcárcel era español y natural de Orense, Galicia ${ }^{10}$ y, "por una de esas circunstancias de la vida, que no son del caso referir aquí" --según indicaba al inicio de su texto-- se hallaba "al servicio de la República Argentina, sirviendo bajo sus banderas en la clase de capitán” (Valcárcel, 1883: 10), concretamente en el "batallón de infantería $3^{\circ}$ de línea del Ejército de la República" cuando comenzó a planificarse el viaje por el Bermejo en el que acabaría participando. En cuanto a los motivos que le llevaron a dejar su país natal con una mano atrás y otra adelante, sólo al final de la narración desvela que fueron de índole política: "Yo había llegado pobre a América, impelido por la política de la madre patria" (Valcárcel, 1883: 75), pero sin mencionar la fecha de su llegada a Argentina. Atendiendo a estas razones, es probable que hubiese abandonado España tras la Revolución de 1868 (la "Gloriosa"); o bien que emigrase antes, en algunos de los contingentes migratorios que se asentaron en el país a partir de 1850 (provenientes del norte español: Galicia, Asturias, País Vasco ${ }^{11}$ ) y que al igual que tantos otros se enrolase como soldado, buscando en el servicio militar una vía de sustento (De Cristóforis, 2008: 120).

Como el mismo Valcárcel explicaba en su libro, tras poner "en juego" todas sus relaciones había logrado que se le confiase la dirección del ejército que acompañó a la expedición fluvial de 1872, empeño al que le movería, tal vez, la posibilidad de un ascenso en su carrera militar. Las recomendaciones conseguidas de cara a alcanzar el "codiciado mando" de esas tropas, explicarían sus muestras de agradecimiento al principio y al final de la obra: "Yo he contraído una sagrada deuda de gratitud con la República Argentina", reza en la dedicatoria de su libro a Bernardo de Irigoyen ${ }^{12}$, quien podría haber sido una de las personas que intercedieron a su favor. Asimismo, una de las frases con las que cerraba su relato permiten confirmar que fue este en sí mismo la forma de corresponder a tales atenciones, declarando haber procurado "nada más, que pagar una deuda de gratitud"; lo cual, dicho sea de paso, le permitía excusarse por el poco cuidado puesto en la "parte literaria" (Valcárcel, 1883: 10, 78). Aunque no lo decía de modo explícito, en definitiva el favor recibido quedaba compensado con una obra que

\footnotetext{
9 Hasta el momento, las indagaciones sobre la figura de César Valcárcel han sido infructuosas, aunque es probable que otra de sus obras (Impresiones de viaje desde la Península hasta Buenos Aires..., de 1882) que no ha sido posible consultar aún, pueda aportar mayores datos. Por lo demás, este autor ni siquiera es mencionado en las otras dos memorias referidas a la expedición (Castro Boedo, 1873 y Araóz, 1886).

${ }^{10}$ En un pasaje de la narración, y a propósito de describir una pesadilla, viéndose amenazado por todo tipo de peligros, el autor no pudo menos que recordar a su madre y la casa familiar en Orense, "entre las riberas del [río] Miño" (Valcárcel, 1883: 13). El origen orensano del autor no se revela sino al final del relato (p. 77).

${ }^{11}$ Entre otros trabajos sobre la inmigración española en Argentina, véase Fernández y Moya (1999) y, en relación con la emigración gallega en particular, la obra colectiva coordinada por Núñez Seixas (2001).

${ }^{12}$ Ministro de Interior bajo la presidencia de Julio A. Roca y uno de los fundadores de la Unión Cívica Radical.
} 
daría a conocer en Europa los afanes civilizadores del gobierno argentino, mostrándolo como adalid de la lucha contra la barbarie, además de difundir el promisorio horizonte que aguardaba a quienes se decidiesen a emigrar. Esto también le habría inducido a modelar su obra pensando en un público europeo: "Como se imprime en Madrid, es más que posible que se lea más aquí, que del otro lado del Atlántico” (Valcárcel, 1883: 62).

No era la primera vez que el autor de Una Expedición al Chaco se embarcaba en empresas de este calibre, pues aseguraba haber participado con anterioridad en "las más recientes expediciones hechas por hijos del país”, como las del teniente coronel Napoleón Uriburu (comandante de las fronteras de Salta), la del alemán Francisco Host "y otros" (Valcárcel, 1883: 10). Una vez llegado con su ejército a las cercanías de Rivadavia, Roldán le comunicó a Valcárcel la orden de retornar a Buenos Aires para informar al Gobierno de los incidentes del viaje y de su relevo por las fuerzas al mando de los citados Uriburu y Host, que habían partido de Salta a su encuentro (Valcárcel, 1883: 36); tal orden le provocó cierto desencanto, puesto que considerándose "uno de los exploradores de estos países", iba a marcharse de ellos "con mucha gloria, pero tan pobre como antes" (Valcárcel, 1883: 36). Desde Salta, emprendió su regreso a Buenos Aires, donde dio por concluida su "comisión ante el Gobierno", obteniendo luego su baja del ejército no sin antes haber sido "emplazado" por Luis María de Campos, "coronel, inspector general de armas", para escribir sus memorias sobre la expedición (Valcárcel, 1883: 77). No resulta aventurado pensar que a través de la difusión de su crónica chaqueña en Europa Valcárcel llegase a obrar, en cierto modo, como un agente de colonización --a semejanza de aquellos que reclutaban inmigrantes en el viejo continente--, como lo sugieren los discursos con tintes propagandísticos a favor de la inmigración europea; una especie de captación literaria --valga la expresión-- de emigrantes, quienes, una vez en Argentina, tendrían allanado el camino hacia el Chaco por medio del transporte a vapor. En este orden de cosas, es factible que a través de los comentarios de un personaje de la narración sobre el canal de navegación y de riego por él construido en las proximidades de sus Estados --como llamaba Valcárcel a la "colonia" creada por el francés Vernuil ${ }^{13}$--, el autor abrigase el propósito de promover el negocio de la compañía privada de vapores que navegó el Bermejo en 1872: “[...] aquí, donde tanta agua sobra, el camino más natural [y más barato] es el canal de navegación, no el ferrocarril", expresaba el colono, mencionando expresamente en otro pasaje del texto a la Compañía de Roldán, que ofrecería un "transporte seguro" a la producción de los pueblos que llegaran "a constituirse definitivamente en el Chaco" (Valcárcel, 1883: $35,43)$.

Concluida su misión, Valcárcel pasó unos días de ocio en Buenos Aires en compañía de Vernuil y de su hija adoptiva, incluyendo paseos por la ciudad y la asistencia a una función en el Teatro Colón, entre otras actividades recreativas (Valcárcel, 1883: 75-76). No tardaría nuestro autor en embarcarse rumbo a Lisboa, travesía que duró cerca de un mes; desde la capital portuguesa y al cabo de tres días de viaje llegó el

${ }^{13}$ Valcárcel (1883: 28). El autor utiliza este término y también otros como "territorios" o "tolderías" (setenta en total) para aludir al poblado establecido por Vernuil en torno a la Laguna de las Perlas. 
19 de septiembre de 1874 a su tierra natal, Orense, "una de las cuatro provincias del antiguo reino de Galicia", recibiendo al día siguiente un telegrama --reproducido en el relato-- de su amigo Vernuil, a la sazón también en Europa tras abandonar su "colonia" chaqueña. Con posterioridad nuestro autor se habría radicado en Madrid, introduciéndose en medios literarios como lo evidencian los nombres de escritores que redactaron el prólogo y la dedicatoria de una de sus obras posteriores. En 1882 vio la luz un primer libro de su autoría, titulado Impresiones de viaje desde la Península hasta Buenos Aires, con la descripción del periplo que lo llevó a Argentina, editando al año siguiente el relato de su viaje de 1872, Una Expedición al Chaco, aunque parte de su contenido lo había ido volcando por entregas en publicaciones tales como $L a$ Ilustración Militar, La América, La Gaceta Internacional de París "y otros muchos periódicos"14 (Valcárcel, 1883: 77). Años después publicó en la Habana la tercera de sus obras conocidas: Del natural. Novela de costumbres contemporáneas $(1888)^{15}$, con prólogo de Aniceto Valdivia, quien, por cierto, resaltaba el mérito de la narración a pesar de "ciertos descuidos de estilo que a trechos la sombrean" (Valcárcel, 1888: 7). Esta novela, que el autor dedicó al conocido escritor vallisoletano Gaspar Núñez de Arce (ibídem, pp. 5-6) ${ }^{16}$, estaba inspirada en hechos de la vida real y su precio de venta fue de "medio peso" (igual coste que el de su libro anterior, Una Expedición al Chaco), conforme indica la portada. La mencionada dedicatoria a Núñez de Arce está firmada en la Habana (marzo de 1888), pudiéndose colegir que Valcárcel había realizado una nueva emigración --quizá destinado como militar-- hacia la Cuba aun bajo dominio español, en búsqueda de nuevos horizontes, aventuras y "emociones", como solía repetir en su relato. Murió en $1889^{17}$, posiblemente en la isla caribeña.

\section{El relato: promesas de un horizonte paradisiaco en las soledades del Chaco}

En primer lugar y como antes apunté, Una Expedición al Chaco representaría la materialización de una deuda de gratitud de su autor por la confianza en él depositada como capitán del ejército de tierra en la exploración de 1872. Considerando este cometido, la obra ostenta algunos de los rasgos que caracterizan las memorias redactadas por exploradores y/o comisionados del gobierno con el fin de informar sobre las vías de comunicación dentro del territorio argentino, con las consabidas referencias históricogeográficas y de tipo "etnográfico" y sobre los recursos naturales, sobresaliendo, en especial, el discurso justificativo de los planes gubernamentales para civilizar el Chaco,

\footnotetext{
${ }^{14}$ De entre los periódicos señalados por Valcárcel, sólo he podido hallar referencias sobre La Ilustración Militar, que comenzó a publicarse en 1880. Algunos ejemplares del siglo XX se encuentran disponibles en la Hemeroteca Digital Hispánica: http://hemerotecadigital.bne.es/details.vm?q=id\%3A0003854579. [Consulta: 13/05/2016].

${ }^{15}$ Esta obra también se encuentra disponible en la Biblioteca Digital Hispánica: http://bdh-rd.bne.es/ viewer.vm?id=0000102465\&page $=1$ [Consulta: 13/05/2016].

${ }^{16}$ La novela lleva prólogo del "distinguido periodista y literato" Aniceto Valdivia (1857-1927), conocido también por su seudónimo, Conde de Kostia. Estudió desde joven en Madrid, donde residió hasta los años 1880 (Depestre Catony, 2009).

${ }^{17}$ Fecha obtenida en la página Web de la Biblioteca Nacional de España, aunque no se consigna la de su nacimiento. Véase: http://datos.bne.es/persona/XX1472195.html [Consulta: 25/04/2016]
} 
repoblándolo con inmigrantes europeos. No obstante, la obra de Valcárcel no constituye en sentido estricto una crónica de viaje, ya que carece de una descripción cronológica de los hitos del itinerario y de las incidencias puntuales habidas en cada uno ${ }^{18}$; de todo esto Valcárcel habla muy poco, mencionando apenas los sitios de algunas paradas de su ejército. Por otra parte, los datos técnicos referidos a la navegación por el Bermejo, salvo la referencia a la avería sufrida por el vapor Leguizamón, tampoco son del tenor de los proporcionados (como es de esperar) por las crónicas de Castro Boedo y Aráoz, ambos a bordo de aquella embarcación. Más bien los inconvenientes mecánicos sufridos por el vapor y que obligaron a suspender la marcha, propiciaron el detenimiento del autor en la narración minuciosa de otros acontecimientos, tales como el incendio en el monte provocado por un grupo de indígenas, episodio del que salieron ilesos los expedicionarios (Valcárcel, 1883: 12).

Como relato de viaje, el libro de Valcárcel presenta otros elementos que caracterizan este tipo de literatura: las descripciones del medio natural, la incorporación de anécdotas y datos de color local, la intertextualidad, las miradas sobre la alteridad (comprendiendo esta no sólo el mundo nativo) y su derivado, las (re)definiciones identitarias. A medida que nos adentramos en el texto se suman ingredientes singulares y de peso que dificultan el encasillamiento de la obra en una tipología concreta (crónica, libro de viajes o memorias, entre otras formas narrativas), aunque tales ingredientes van a la postre en la misma dirección que los demás componentes y, por tanto, no invalidan el carácter apologético de la obra acerca de los beneficios de la inmigración europea y de la superioridad de este componente humano para hacer del Chaco un mundo civilizado y productivo, en consonancia con los fines de control de los territorios salvajes. Me refiero, en concreto, a la introducción de una trama novelesca a partir de la irrupción en el relato del francés Mr. Vernuil (constructor del todavía menos creíble "palacio" en las selvas y jefe de una próspera colonia de "tolderías" tobas, donde todo era orden y civilización) y de su hija adoptiva, la mestiza Notaj/Diana. Emerge aquí la faceta de relato novelado de un viaje, con el aditamento de una historia sentimental: un triángulo amoroso del que forman parte la mestiza, el oficial Sandoval y el doctor Remini (ambos miembros de la expedición de Valcárcel), situándose al margen el autor, a pesar de haber caído él también en las redes seductoras de la joven. Al final del texto justificará esos deslices fantasiosos en aras de abarcar un público más amplio con una obra divulgativa, pero sin apartarse del leit motiv de la narración; así, y a propósito de la muerte del naturalista Jules Crevaux en el Chaco ${ }^{19}$ y tras destacar "tan sensible

${ }^{18}$ En un estudio sobre los Naufragios de Álvar Núñez Cabeza de Vaca, su autora destaca que "en el género cronístico predomina la narración de una serie de hechos con la finalidad de mostrar la mejora o el empeoramiento del héroe" (Borrero Barrera, 2000: 201). A pesar de carecer de un desarrollo cronológico preciso y detallado del itinerario, en el caso estudiado aquí en cierta manera se cumple esa transformación del protagonista (héroe) del relato, en cuanto a las circunstancias que marcaron su experiencia en el Chaco, como luego se verá.

${ }^{19}$ Creveux perdió la vida en 1882, durante una misión científica en el Chaco. Los tobas, chorotes y tapietés fueron acusados de ser los responsables de su muerte así como la de todos los miembros de su equipo (véase al respecto: Arce Birbueth, 2003: 17). Por su parte, Valcárcel (1883: 78), al comentar este suceso, lo achacaba en parte a la "imprudente confianza" de Creveaux, fruto del desconocimiento de la peligrosidad 
desgracia para los altos intereses de la ciencia, la colonización y el porvenir de América del Sur", el autor afirmaba que todas estas "trascendentes cuestiones" estaban presentes en su obra "bajo una forma cuyo único objeto era dar popularidad a una lectura que, tratada bajo otro aspecto, solo alcanzaría un reducido número de lectores" (Valcárcel, 1883: 78. Subrayado añadido). Por lo demás, esta inclinación por la ficción no resulta extraña, atendiendo a que años después de su Expedición al Chaco, Valcárcel acabó publicando la antes citada novela de costumbres.

Los viajes exploratorios realizados a lo largo del siglo XIX tuvieron un claro "interés geopolítico" (Areces, 2008: 165), un rasgo que en gran medida define a la expedición de 1872 junto a su composición mixta, ya que en ella participaron militares, geógrafos y miembros de una compañía privada de vapores, movida por intereses comerciales. De entre los escritos referidos a esta exploración --y sin ánimo de una comparación exhaustiva, que no cabría aquí-- el de Valcárcel comparte rasgos comunes con los dos restantes (Castro Boedo, G. Aráoz) en lo que respecta a la inclusión de datos sobre población y recursos naturales, así como de referencias históricas sobre los intentos de conquista y colonización del Chaco. Y, en especial, en el marco del proyecto de nación desplegado por el Estado, las tres memorias desarrollan una misma línea discursiva en torno a las imágenes construidas sobre este territorio y a las ideas de civilización y progreso, a través de la inmigración y colonización europea ${ }^{20}$. Los beneficios de esta son resaltados una y otra vez en el texto que nos ocupa, como camino de salvación para la población que sufría la pobreza en el viejo continente: "Nadie piensa en América más que cuando está arruinado, o cuando el hambre lo acosa en Europa, o tal vez en condiciones peores; pero aquí, aunque venga desmoralizado, ordinariamente se moraliza" (Valcárcel, 1883: 28).

En Una Expedición al Chaco el propio autor definía el viaje organizado en 1872 por la Compañía de Natalio Roldán como una "exploración científica"21 (Valcárcel, 1883: 10), aspecto sobre el que cabe apuntar algunas consideraciones. En primer lugar, este tipo de viajes no constituían algo inédito, teniendo como antecedentes más próximos (en lo que al periodo colonial se refiere) las expediciones de científicos enviadas a América durante el reinado de Carlos III, empresas que simbolizaron una "apropiación intelectual" de territorios, de sus recursos naturales y de sus habitantes, "como una parte integral de la toma de posesión efectiva de los mismos en la época de la Ilustración" (Weber, 1998: 166). En el caso del viaje exploratorio aquí tratado, como tantos otros practicados en la época, representaba la vía de legitimación de un proyecto

de algunos grupos chaqueños.

${ }^{20}$ En su memoria, publicada con posterioridad a la campaña del general Victorica al Chaco (1884), Aráoz destacaba que gracias a esta operación militar "hemos de ver nuevas poblaciones como brotadas del suelo por obra de encantamiento", puesto que sólo la periferia de aquel territorio (el Chaco austral) se hallaba entonces "poblada por hombres civilizados, al frente de sus establecimientos agrícolas" (Araóz, 1886: 20).

${ }^{21}$ El énfasis en el carácter científico de los viajes exploratorios como aquellos que se hicieron al Chaco y a otras zonas de Argentina con miras al establecimiento de colonos y a la explotación de sus recursos naturales, servía a los fines de la "construcción" de territorios fuera del control efectivo del Estado; así, en ese contexto, "[...] la cientificidad entendida como pretensión de neutralidad, objetividad o referencia perfecta a realidades objetivas y patentes juega un rol decisivo" (Cecchetto, 2015: 3). 
en el que los intereses públicos y privados confluían en total armonía: por un lado, los del Estado nacional, en el marco de una estrategia geopolítica-económica que perseguía la consolidación territorial y el re-poblamiento e incorporación de los desiertos ${ }^{22}$ del Chaco al marco productivo agro-exportador y, por otro, los de una compañía privada de vapores --“más bien patriótica que mercantil”, según Valcárcel (1883: 40)--, que esperaba pingües beneficios de su uso en la navegación del Bermejo. La viabilidad de este proyecto descansaba en buena parte en los conocimientos geográficos y técnicos necesarios para doblegar las complicaciones en el tránsito por aquella vía fluvial. En un trabajo sobre las expediciones científicas al Chaco y a otras zonas del país en el último cuarto del siglo XIX y su relación con la "legitimación de los saberes geográficos"23, se define a los protagonistas de esos viajes como "agentes estatales-militares y técnicos que exploran territorios aún no pacificados o sometidos" (Cecchetto, 2015: 2) 24. En este aspecto, Valcárcel no olvidó aludir a los menesteres científicos de la expedición, como los de "reunir ejemplares de plantas, animales, tierras, etc. que ofrece la mineralogía y zoología del Chaco" (Valcárcel, 1883: 20). No obstante, a través de Vernuil, en un diálogo con el autor, se nos ofrece una visión más realista: "Por mi parte puedo hablar de la abundancia de la flora y de la fauna, pero no puedo hacer una clasificación científica, y además, dicho por mí, dirán en Europa: ¿y quién lo dice? -Un Mr. Vernuil, que vivió trece años en el Chaco. Como comprendéis, esto no es bastante" (1883: 53) ${ }^{25}$. Sin duda, detrás de estas apreciaciones emerge una cuestión de no poca relevancia en el marco del capitalismo en expansión, dentro del cual la "acumulación capitalista" operada en Europa a lo largo de los siglos, suponía una "sistematización de la naturaleza [que] lleva esta imagen de acumulación a un extremo totalizado, y al mismo tiempo modela el carácter extractivo, transformador del capitalismo industrial [...]. Como construcción ideológica, la sistematización de la naturaleza representa el planeta apropiado y reorganizado desde una perspectiva europea y unificada" (Pratt, 2011: 81).

Si bien la participación de Castro Boedo ${ }^{26}$ en la expedición de 1872 suponía la aportación de la ciencia geográfica al estudio de la navegabilidad del río Bermejo, cuestión sobre la que enfatizaba en su informe, al mismo tiempo quedaba reflejado con meridiana claridad su involucramiento en el proyecto liberal de la época, obrando

\footnotetext{
${ }^{22}$ Sobre este concepto aplicado en concreto al caso del Chaco, existe una considerable bibliografía. Cito, a título ilustrativo, Lois (1999); Dávilo y Gotta (2000) y Zusman (2000).

${ }^{23}$ Los informes de estas expediciones geográficas "se asocian también al proceso de institucionalización de la ciencia y la técnica en el país, en tanto son éstas las que proveerán los especialistas necesarios para llevarlos a cabo" (Cecchetto, 2015: 4).

${ }^{24}$ A propósito de las pretensiones científicas de ciertos expedicionarios, es oportuno traer a colación la tipología de viajeros por el Amazonas realizada por Pérez (2006: 195), señalando entre aquéllos a quienes "toman a la ciencia como excusa para sus peregrinaciones en busca de a saber qué --o científicos extensivos, valga la expresión--".

${ }^{25}$ Por otra parte, aunque Valcárcel se arrogaba el título de "explorador" del Chaco, al final admitiría que la información ofrecida en su relato provenía de "las impresiones que Mr. Vernuil me había comunicado" (Valcárcel, 1883: 78).

${ }^{26} \mathrm{Su}$ obra está dedicada al presidente de la comisión directiva de la Compañía de Navegación del Río Bermejo, Francisco G. Molina, a quien debía "la ocasión de practicar en la Expedición Roldán los estudios que este libro contiene" (Castro Boedo, 1872. Dedicatoria).
} 
en todo caso como un científico funcional a los intereses del gobierno. Convencido de la "fecunda importancia" y la "inagotable riqueza" del Chaco (que hacía extensible a Patagonia), "más que suficientes para excitar por muchos siglos toda ambición de un mundo de inmigrantes", aquel "sabio doctor" (como lo llamaba Valcárcel) se había abocado a "estudiar con la posible detención, curiosidad y esmero la navegación del Bermejo" (Castro Boedo, 1872: VI), un factor crucial para los planes de colonización. Un discurso del que nuestro cronista se hacía eco: "La expedición sabía ya, que para poblar el Chaco, tenía el elemento más importante, cual era la gran vía de comunicación fluvial por donde transportar sus tesoros" (Valcárcel, 1883: 20). En toda la narrativa referida a estos viajes exploratorios, y la de Valcárcel no sería la excepción, se dibujaba un horizonte de riquezas que coadyuvaron a la "construcción de un territorio" bajo la clave de "paisaje del progreso" 27 . Por otra parte, el hecho de sobreabundar en la magnificencia de la naturaleza ${ }^{28}$, además de seguir el estilo descriptivo al uso cuando se trataba de zonas con recursos explotables, parece albergar la intencionalidad de exaltar --para usar un término recurrente en el relato de Valcárcel-- a su vez la imaginación de potenciales colonos europeos.

En este orden de cosas, la inmigración europea sería un instrumento poderoso en manos del Estado nacional para afianzar su dominio en el Chaco, que años después habría de ser objeto de expediciones militares como réplica de las acometidas en el sur contra los mapuches. La idea de tierra virgen y despoblada, apta para la colonización europea, se patentiza en expresiones a menudo repetidas como "los desiertos" o "las inmensas soledades del Chaco" (Valcárcel, 1883: 20), en las que los nativos eran invisibles ("no formaban sociedad", en palabras de J. B. Alberdi ${ }^{29}$ ), conceptos que nutren los argumentos que a lo largo de la obra irán desgranando el autor, el francés Verneuil y el argentino Castro Boedo (a quien se da entrada en la narración, mediante un par de intervenciones breves), justificando el dominio blanco para redimir el Chaco: "¡Veintisiete mil leguas cuadradas, perdidas á la actividad del hombre, en poder de algunas tribus nómadas de indios; con bosques de riquísimas maderas; abundantes sudaderos de aceite mineral; preciosas minas de sal, azufre, metales preciosos; conocidos lagos, criaderos de perlas!" (Valcárcel, 1883: 9-10).

La naturaleza chaqueña era vista desde la perspectiva de su productividad, que podía hacerse realidad merced a la providencial intervención europea, argumento que constituye uno de los ejes discursivos del relato, en el que desde el inicio sale a relucir el propósito de tomar posesión de un territorio y extraer sus riquezas, lo que llevaba implícito la domesticación de sus salvajes pobladores: "Un problema agita a la

\footnotetext{
${ }^{27}$ El concepto ha sido analizado en profundidad por Pedro Navarro Floria (2007). Paisajes del progreso. La resignificación de la Patagonia Norte, 1880-1916. Cit. en Cecchetto (2015: 3).

${ }^{28}$ También la crónica de Castro Boedo (1876: VI) reproduce esas connotaciones paradisíacas, que configuraban "el más delicioso, extenso y rico panorama" que ofrecía el Chaco.

${ }^{29}$ Esta visión del mundo indígena la hallamos ejemplificada a la perfección en ese fabricado diálogo entre Castro Boedo y "la india mestiza" Notaj/Diana, al preguntarle aquél a esta joven si deseaba "conocer la sociedad", en la tácita consideración de que su pasado entre los indígenas llevaba tácita la inexistencia de vida comunitaria (Valcárcel, 1883: 43).
} 
humanidad en el vasto campo de su actividad utilitaria" (Valcárcel, 1883: 9), sentenciaba de entrada nuestro autor, desvelando el sentido último de todo su escrito y los alegatos en él contenidos, que no esconden la avidez capitalista en la búsqueda de nuevos horizontes de expansión, disfrazada de "empresa de civilización" (Reguera, 2008). Este aspecto ha sido también destacado en un estudio sobre el informe (1877) del ingeniero Arturo Seelstrang, al frente de la Comisión Exploradora del Chaco, en el que "cada minuciosa descripción e inventario está enunciada teniendo como eje principal las posibilidades que cada elemento descripto tienen para su aprovechamiento productivo" (Cecchetto, 2013: 32). De igual modo, en la obra aquí analizada abunda la mención de las aplicaciones prácticas de los productos que ofrecía el Chaco, en una visión utilitaria del territorio y sus recursos, mediante una prolija enumeración de las especies de su flora y su fauna, ofreciendo el pormenor de sus utilidades como en el caso del tanino, importante para el negocio de pieles (uno de los productos con los que traficaban los franceses, como se verá más adelante), ya que espolvoreando la sustancia obtenida de las vainas del árbol se evitaba la putrefacción del cuero (Valcárcel, 1883: 14-15). A ello se agregan las virtudes medicinales de ciertas especies vegetales, con el fin de despertar la atención de los lectores europeos sobre los milagros curativos de la flora autóctona. A lo largo del texto las alusiones se repiten cada vez que la ocasión se presta: hasta la descripción del "palacio" que había levantado el francés Vernuil le serviría a Valcárcel de pretexto para demostrar la prodigalidad del bosque chaqueño, materializado en el mobiliario, hecho con madera de palo santo, ébano y quebracho, así como la riqueza de la fauna, palpable en las alfombras que lucía la vivienda, fabricadas con pieles de animales (1883: 23). Por su parte, Vernuil hacía una detallada descripción de los productos minerales y de sus correspondientes beneficios para la industria y el comercio: sal, alumbre, piedra, caolín, alabastro, tiza, yeso, etcétera, advirtiendo una vez más que a esta información le faltaba "autoridad", siendo necesario un "reconocimiento científico" mandado por el gobierno (1883: 53). Cabe subrayar aquí, además, la influencia de Humboldt, formado en "ese espíritu positivista y de fascinación por la naturaleza", cuyo conocimiento tenía por fin "permitir al hombre un mayor poder sobre la misma, facilitar su explotación posibilitando así el progreso, tan ilimitado como el propio avance del saber y de la ciencia" (Corbera Millán, 2014: 40).

En Una Expedición al Chaco emergen además algunos de los tópicos consagrados en la literatura de viajes, como se observa en la descripción del entorno natural; en este sentido, el autor es reiterativo en el uso de adjetivos como "risueña/o" --entre otros similares--, expresión habitual en la narrativa decimonónica: son "los topos de la simpatía de la naturaleza que procede del mito de Orfeo, el topos del paisaje ideal de la Arcadia o el topos del locus amoenus", como señalaba W. Raible (cit. en Ortega Román, 2006: 212). En la apreciación de la naturaleza chaqueña no faltan otros elementos de la estética romántica, poniendo al lector ante paisajes mágicos que despertaban los sentidos y resumían "el cuadro sublime de la creación en el Chaco", una naturaleza amable que ofrecía a la vez un sesgo salvaje: a la par de lagunas hermosas, perfumes vegetales, bosques espesos, cielos puros y "estrellas más refulgentes que en otra parte del globo", hay animales que "rugen y braman" (Valcárcel, 1883: 9), conformando el 
todo "una naturaleza salvaje y sugestiva, hondamente romántica" (Cruz Casado, 2003). Otros ingredientes acercan nuestro relato a los de los viajeros de esta época, en cuanto a las manifestaciones de la subjetividad, no sólo en la percepción emotiva de la naturaleza y el paisaje, en los recuerdos de la infancia o en situaciones de peligro sino también en la confesión de sentimientos a que dan lugar tanto los episodios verídicos --relativos a las expediciones fluvial y terrestre de 1872-- como la trama novelesca, con personajes ficticios que interactúan con otros "reales", tocándole al lector "adivinar dónde concluye la verdad y empieza la fantasía" (Valcárcel, 1883: 78).

Otro aspecto a destacar de Una Expedición al Chaco es la intertextualidad ${ }^{30}$, una faceta consustancial a los libros de viajes, siendo dable observar cómo se filtran en esta obra tanto el acervo literario peninsular como el americano: "De hecho, el discurso es un universo textual y no es de extrañar que haya intertextualidad entre los libros de viajes, las crónicas, las biografías y otros géneros" (Borrero Barrera, 2000: 201). Incluso el mismo autor, nada más comenzar su relato, advertía haberse documentado antes de emprender su expedición: “[...] registré cuanto volumen encontré en las bibliotecas que hablaran sobre el Chaco, desde Ayolas hasta nuestros días" (Valcárcel, 1883: 10), llegando así a disponer de todo un corpus de información, fraguado a lo largo de los siglos con imágenes preconcebidas sobre el territorio y sus pobladores. En este punto no están ausentes los patrones descriptivos de las crónicas de la conquista y de la "etnografía" jesuítica, con su clásica percepción de los nativos y sus costumbres, aunque Valcárcel parecía más interesado en ahorrarle al lector estas descripciones por lo mucho que se había leído de ellas, prefiriendo más bien "historiar" sus experiencias a partir del encuentro con Vernuil (1883: 20). Tampoco debe descuidarse la impronta dejada en América por los viajeros naturalistas como Humboldt y Bonpland (ambos citados por el autor), así como la retórica de los ensayistas del ámbito rioplatense, que trasunta un modelo de nación, un proyecto de país del que se hacía eco el autor. Un ejemplo bastaría para ilustrar esta huella, citando el pasaje que evocaba el pensamiento sarmientino en lo que se refiere a la antítesis campo-ciudad y al papel de Buenos Aires como portaestandarte de la modernidad y el progreso: "Buenos Aires no podía dormirse. La Atenas de la América del Sur tenía que despertar, y despertó”, para emprender su acción civilizadora que encarnaba los propios ideales europeos y "dar luz al hombre primitivo, recibiendo aquellos, en justo premio, los dones de su virgen y encantadora naturaleza" (1883:10).

En Una Expedición al Chaco también encontramos pasajes que aportan colorido al relato, como las referencias al uniforme "a la moda francesa" de los soldados argentinos (Valcárcel, 1883: 13), los sofisticados y abundantes platos del menú para los oficiales y la tropa en el fantasioso banquete en las selvas, donde no escasearon los vinos franceses (Valcárcel, 1883: 15), así como otras anécdotas, relacionadas con la estancia de Valcárcel en Buenos Aires antes del retorno a Europa, compartiendo paseos con Vernuil y su hija y recorridos por los edificios emblemáticos de la capital argentina (Casa Rosada, Congreso de los Diputados y Banco Hipotecario, entre otros), actividades estas coronadas con la velada musical en el teatro Colón de Buenos Aires,

${ }^{30}$ Sobre este aspecto de la literatura de viajes, véase también Oro y Rodríguez (2008: 23). 
donde el tenor español Julián Gayarre interpretó el Rigoletto (Valcárcel, 1883: 75-76). Por otra parte, el libro está ilustrado con un conjunto de grabados de Laporta Valor ${ }^{31}$, tanto en la portada como en su interior, tal vez encargados por Valcárcel y realizados a partir de dibujos o de las tomas fotográficas a indígenas y expedicionarios, realizadas al levantar un campamento según relataba el autor: "Se bajó la cámara oscura y se sacaron algunos retratos"; gesto que, por lo demás, formaba parte de la estrategia de impresionar (en este caso con la máquina fotográfica) a los indígenas y demostrarles que "aunque en menor número, éramos superiores a ellos por los muchos medios de que disponíamos, buscando el efecto moral" (Valcárcel, 1883: 19). En cuanto a las imágenes en sí, está fuera de toda duda su importancia como soporte del discurso para marcar, en este caso, el contraste entre civilizados y bárbaros señalado en su versión textual.

\section{Representaciones de la diversidad: "civilizados" y "primitivos"}

En este apartado expondré algunas reflexiones en torno a las manifestaciones identitarias en las "zonas de contacto" según la definición de Pratt (2011: 31) enfocando dos figuras masculinas que asumen protagonismo en el relato, el propio autor y Vernuil, que actúan y hablan desde su condición de europeos (español y francés, respectivamente). Aunque, también, uno y otro representan idiosincrasias nacionales ${ }^{33}$ ya que, como bien señala De Cristóforis (2010: 116) al tratar de los viajeros europeos por tierras rioplatenses: "El sentimiento nacionalista era lo suficientemente fuerte en estos autores como para posicionarlos en un lugar especial, de superioridad con respecto a lo que veían, escuchaban y sentían en los ámbitos que recorrían”. Sin embargo, la definición de identidades, en un escenario de interacciones entre sujetos de variado origen, da lugar no solo a un proceso de reafirmación de ciertos componentes de la propia idiosincracia sino también a la incorporación de nuevos rasgos distintivos como resultado del fenómeno de transculturación operado en esos espacios a los que se refiere Pratt (2011).

El viaje coloca al protagonista frente a sí mismo y frente a los otros. Identidad y alteridad son pues dos cuestiones inherentes a la narrativa resultante del tránsito por mundos diferentes al de origen; es a través de la experimentación y reafirmación de su propia diferencia frente a los otros que el viajero construye su discurso identitario: "La alteridad es constitutiva y constituyente de la persona loquens del relato de viaje"

${ }^{31}$ Enrique Laporta Valor (1842-?) fue un destacado grabador de origen alicantino. Véase al respecto: Real Academia de Bellas Artes de San Fernando. Catálogo de Artistas del siglo XIX. Disponible en http://www.realacademiabellasartessanfernando.com/assets/docs/laminas/laminas_sxix_artistas.pdf [Consulta: 23/04/2016].

32 Pratt desecha el término de "fronteras" y aplica el concepto "zonas de contacto" al tratar de "los espacios de los encuentros coloniales" y de los fenómenos de transculturación que en ellos se producen (Pratt, 2011: 33 ).

${ }^{33}$ Dentro de la misma Europa, las diferencias nacionales pueden apreciarse, por ejemplo, en el viaje científico protagonizado por L. Gómez Pardo, un ingeniero español del siglo XIX, que en su recorrido visitó fundiciones y establecimientos mineros de Centroeuropa y Francia. A lo largo de su travesía, la perspectiva desde la que describía el variado conjunto de personas con las que interactuó (aparte de las relaciones estrictamente profesionales) y los lugares visitados, muestra la defensa de su nación. Al mismo tiempo, las fronteras nacionales aparecen marcadas a través de una visión crítica del quehacer científico de los franceses con respecto a los alemanes, por ejemplo. Véase al respecto Vitar (2010: 93-109). 


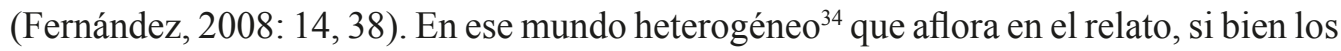
discursos de Vernuil y Valcárcel se complementan en cuanto a delimitar sus respectivos rasgos nacionales, en ellos aflora además cierto sentimiento de pertenencia a una patria grande, Europa, de cara al propósito de justificar su superioridad y la necesaria presencia de sus gentes para civilizar el Chaco. Así parecen confirmarlo las palabras de Vernuil, al invitar a Valcárcel a una estancia en sus tolderías, "pues sabréis cosas muy curiosas y de grande utilidad para nuestra querida patria" (Valcárcel, 1883: 23).

\section{Un militar español en el Chaco}

Como yo narrador, la propia figura del autor suscita variadas interpretaciones, en cuanto al manejo de estrategias discursivas para trazar su perfil identitario, que construye también con las opiniones vertidas por otros con quienes interactúa. En primer lugar, cabe destacar su condición de español, embarcado en la exploración de un territorio indígena sobre el que se proyectaba la imagen de salvaje y hostil, en función de su legendaria resistencia al dominio colonial. Frente a la otredad el autor se erige en observador crítico aunque también él era en sí mismo un otro, tanto como representante de la sociedad hegemónica como por su estatus de extranjero en Argentina y al mismo tiempo sirviendo en su ejército. De modo singular, en este viajero español renacía la conciencia de un pasado de conquista y posesión de América: "El imaginario del viaje de descubrimiento-conquista tenía mucho que ver con unos mitos colectivos, el exotismo, el sueño colonial, el imperio, y con los sueños de unos individuos, los grandes viajeros" (Augé, 2006: 13). Cabe suponer que, no siendo oriundo del país, la experiencia del viaje sumergió de lleno a Valcárcel en un proceso de reafirmación identitaria, en el que pesaba el influjo del imaginario peninsular sobre el mundo americano. En los umbrales de su aventura en un territorio que sus antepasados no habían logrado someter, Valcárcel parecía empeñado en reeditar la gesta de los descubrimientos, llegando a equiparar su expedición con el viaje de Colón y, más aún, a un querer ponerse en la piel de los conquistadores más nombrados. A punto de partir al Chaco, no pudo dejar de recordar "una fecha memorable para España y América; el 3 de agosto de 1492, en el puerto de Palos, habiendo tenido también nosotros otros zumbones y miserables que nos dirigían sangrientos epigramas" (Valcárcel, 1883: 3), disparándose su imaginación al punto de soñar, además, "con el ataque de mil o más indios, con Hernán Cortés y sus héroes legendarios" (Valcárcel, 1883: 10).

Valcárcel va desgranando sus señas de identidad a lo largo del relato, resaltando la índole de su "naturaleza", hecha de una "imaginación exaltada" y amante de "las emociones y lo desconocido", que le hacían experimentar de antemano "la emoción del ataque de una manada de tigres, y qué sé yo cuántas cosas más, que mi calenturienta

\footnotetext{
${ }^{34}$ En la expedición de 1872, fuera de los nombrados expresamente, con seguridad participarían otros extranjeros, ya fuese como integrantes de la tripulación del vapor Leguizamón o bien de la soldadesca conducida por Valcárcel. En un pasaje del texto el autor aludía a la nacionalidad de un miembro de su ejército, pero sin darle nombre propio: "Entre nuestros soldados había un italiano que tocaba el acordion [sic] y los dejó [a los indígenas] maravillados" (Valcárcel, 1883: 19).
} 
imaginación fabricaba"(Valcárcel, 1883:10). Este discurso presenta ciertas connotaciones que denotan el poso de lecturas y de figuras literarias convertidas en un mito nacional. En esta línea, habría una cierta identificación con el Quijote, una asociación entre los valores que movían las acciones del caballero de la Mancha y los atributos con los que Valcárcel iba diseñando su propio personaje. Parte de su idiosincracia eran virtudes tales como la valentía, la heroicidad y el honor, que sacaba a relucir en la narración de episodios dramáticos, como un ataque de fieras en las cercanías de Lacangayé, al que hizo frente para preservar la vida de sus hombres: "Por encima de mi vida estaba el honor [...]. A medida que arreciaba el peligro, adquiría mayor presencia de ánimo. [...] ¡Qué emociones! Mi naturaleza española estaba satisfecha" (Valcárcel, 1883: 1213). Tal vez entre esas "emociones" que esperaba de su viaje se hallaba una aventura amorosa, de la que asoma un primer atisbo en el encuentro con unos grupos tobas dando lugar al escarceo con una "joven india", a la que regaló "un espejo de bolsillo". El episodio, reducido a un par de diálogos y al intercambio de dones, era rematado con los pormenores de la despedida, momento en el que la mujer le obsequió una ramita de nardo encargándole que no la botase, “[...] porque sería botarme a mí”; recomendación a la que respondía el viajero: "Adiós, querida chinita, le dije enternecido señalando el cielo; Tatá ${ }^{35}$ quiere que nos separemos" (Valcárcel, 1883: 19). El conocimiento posterior de la mestiza Notaj/Diana tendría otros ribetes, por las circunstancias que más adelante señalaré, aunque en el hipotético romance de Valcárcel con esta mestiza sus expectativas resultarán frustradas, quedando como el héroe fracasado en la búsqueda del amor ${ }^{36}$.

El autor puede ser analizado también a través de la percepción que los otros tienen de él, en concreto Vernuil y su hija (representando ambos la voz misma del narrador), cuyos comentarios sobre los españoles completan el perfil identitario de Valcárcel quien, a su vez, incorporaba una dosis de autocrítica sin llegar a velar las bondades nacionales: "El español --le expresaba Vernuil--, si tiene vicios incorregibles, en cambio tiene virtudes verdaderamente legendarias; es noble, franco, generoso..." (Valcárcel, 1883: 36). Por otra parte, las circunstancias vitales del autor lo colocaban en una situación ambigua, que bien sintetizaba al presentarse al colono francés ${ }^{37}$ : "Yo también soy extranjero hasta cierto punto [...]. Soy español de nacimiento; de aficiones americano, y más que americano, argentino" (Valcárcel, 1883: 20). Frente a otro europeo la visión del proceso independentista del continente, le serviría para defender, como se diría hoy, la "marca" España: "Una emancipación sangrienta nos ha separado de esta parte del mundo, que solo el genio español supo conquistar para la civilización" (Valcárcel, 1883: 51). Una sentencia que no excluía la mirada condescendiente y paternalista hacia los argentinos, esos "hijos impacientes" (Valcárcel, 1883: 20) que

\footnotetext{
${ }^{35}$ En cursiva en el original.

${ }^{36}$ Sobre el sentimiento del amor asociado a los viajes, en especial los realizados por mar, Alicia Schniebs apunta que: "[...] la relación entre viaje y pasión es casi tan vieja como la literatura occidental que no necesita demostración, pues basta recordar qué hecho desencadena la travesía de los griegos hacia Troya" (Schniebs, 2008: 120).

${ }^{37}$ Al presentarse a Vernuil, Valcárcel decía haberlo hecho en francés, aunque en el texto sus palabras figuran en español.
} 
rompieron los lazos con la metrópoli, afluyendo una vez más la exaltación de las virtudes nacionales al manifestar a Diana que España sería siempre "la madre cariñosa de sus hijos rebeldes de ayer". Palabras a las que respondía aquélla: "Era necesario que de un pecho español salieran tan nobles palabras" (Valcárcel, 1883: 51-52). Asimismo, la pobreza en la que Valcárcel se halló al final de sus días en Argentina, sobrellevando la situación con estoicismo, también le ayudó a configurar otra faceta del personaje construido sobre sí mismo, ya que ante sus reticencias --por una cuestión de "honor"-- a aceptar el dinero ofrecido por Vernuil para remediar sus penurias, este le respondió: "No seáis español a lo Quijote" (Valcárcel, 1883: 76).

En otro orden de cosas, el compromiso ideológico del autor con el proyecto liberal de la época es algo patente en la narración, aunque ello no invalidaba el ejercicio crítico sobre la ineficacia de las políticas seguidas por los gobernantes argentinos --que hacía extensibles al periodo hispánico-- con relación a los indígenas del Chaco: “[...] unos ni otros no tienen nada que echarse en cara", puesto que "sus reducciones ${ }^{38}$ y sus fortines, o no llenaban por completo su objeto, o los dejaban expuestos al primer empuje de estos hombres primitivos" (Valcárcel, 1883: 31). Al mismo tiempo, el pasado criollo inmediato es condenado como oscurantista, con referencia a las "dictaduras" de Francia en Paraguay y de Rosas en el Río de la Plata; en este sentido, el discurso del autor es previsible, dado su carácter de "comisionado" de un gobierno cuyo proyecto simbolizaba el triunfo sobre el rosismo. En cuanto a la visión del territorio, la obra de Valcárcel está hecha a imagen y semejanza de los informes sobre otras expediciones al Chaco, manifestando plena sintonía con los objetivos civilizadores del Estado argentino, toda una garantía de seriedad para los emprendedores e inversionistas del viejo continente. Las alusiones a los "tiranos" de un pasado histórico reciente, los "Nerones y Calígulas de los tiempos modernos", daban pie al autor para denostar su antieuropeísmo, pues "retrajeron de una manera notable la cooperación que hoy se le pide a Europa" (Valcárcel, 1883: 51). El discurso misógino acompaña a las diatribas contra los "dictadores" hispanoamericanos; la condena a los tiranos se hacía extensiva a sus esposas así como a algunas figuras femeninas de las luchas independentistas, con el rechazo implícito a la injerencia femenina en espacios reservados a lo masculino. Véanse por ejemplo los comentarios sobre la peruana Cipriana Latorre de Vivanco, cuyas artes seductoras, decía Valcárcel, habían provocado el vuelco de las tropas enemigas a favor de su esposo o el párrafo dedicado a otras mujeres, como “[...] la señora de Gamarra, en el Perú mismo, y Elisa Linch en el Paraguay, y Manuelita la hija de Rosas, que han sido otras tantas matronas que dispusieron á su antojo de los destinos de un pueblo, teniendo por única ley el capricho" (Valcárcel, 1883: 51).

La cuestión de la inmigración y colonización europea para modernizar el Chaco, que ocupa gran parte del relato, demuestra la plena identificación de su autor con el proyecto político argentino y con los principios rectores del liberalismo económico. Como destaca De Cristoforis (2010: 117), “los viajeros también se convertían en engranajes de la reproducción ideológica del sistema socio-económico al que pertenecían: el capitalismo

\footnotetext{
${ }^{38}$ Véase también la crítica a la obra misionera en el Chaco en Castro Boedo (1872: 262).
} 
en expansión". Así, el relato transmite sin ambages los dictados del capitalismo que, en aras del aprovechamiento productivo de los territorios indígenas, abogaba por el "buen trato" a estos últimos, argumento sostenido de modo unánime por Valcárcel, Vernuil y Castro Boedo. Al respecto, resultan acertadas las observaciones de Pratt (2011), quien aplica la idea de "anticonquista" al discurso de los libros de viajes más modernos (a partir del siglo XVIII), donde emerge el uso de "estrategias de representación por medio de las cuales los miembros de la burguesía europea tratan de asegurar su inocencia al mismo tiempo que afirman la hegemonía y la superioridad europea" (p. 35. Subrayado añadido). Los comisionados del gobierno argentino también actuaron movidos por ese espíritu, enfatizando en la benevolencia de una política disfrazada de asistencialismo que venía a suplantar el requerimiento compulsivo de los tiempos coloniales, como queda muy bien reflejado en el exhorto dirigido por Castro Boedo a los "indios amigos del Chaco" a oír el mensaje del presidente argentino que, enterado "de lo pobrecitos" que estaban, había enviado esa expedición para ayudarles a conseguir una vida mejor (Valcárcel, 1883: 16). La pobreza, igual que en los tiempos hispánicos, era el caballito de batalla para legitimar los propósitos de dominación.

Otros aspectos de interés en cuanto a las pautas culturales que delimitaban fronteras nacionales pueden encontrarse en cuestiones relacionadas con la vida cotidiana durante la expedición de 1872. En el plano de la gastronomía, por ejemplo, Valcárcel trazaba la diferencia entre las costumbres alimenticias españolas y las argentinas (en ocasión del "festín" organizado después de haber vencido el peligro del incendio en el monte) debido a la falta de legumbres, un ingrediente habitual en la dieta española e "imposible de todo punto de proporcionárnoslas sin acudir a las reservas de a bordo [del vapor Leguizamón], [...] pero por otra parte, el argentino se pasa bien sin ellas y nosotros nos contentamos con una ensalada de pimientos de Calahorra"39 (Valcárcel, 1883: 15). Asimismo, para festejar a la tropa durante un descanso, la preparación de una paella que, "aunque es plato nacional en España, es importado, como nuestro idioma y costumbres, en el pueblo argentino" (ídem), también daba pie para incidir en el legado español, esta vez en lo culinario. En este plano, están presentes los tópicos sobre la cultura francesa, por la que el autor no ocultaba su admiración, aludiendo al sibaritismo (Valcárcel, 1883: 28) y a la excelencia de su cocina, no privándose de enumerar en esa lengua los platos del "menú de los oficiales" preparado a orillas del Bermejo y regado con vinos como el ¡Château Lafite!: "Dispénseme, lector; hablando de comer, hay que elegir el idioma francés: creo que sabe mejor lo que se come" (Valcárcel, 1883: 15) y... lo que se bebe, según se colige de la anécdota.

\footnotetext{
${ }^{39}$ Producto típico de esta localidad de la provincia de la Rioja (España).
} 


\section{Vernuil, su "corona salvaje" y su hija mestiza}

La puesta en escena de Monsieur "Gustavo" Vernuil ${ }^{40}$ en el relato nos introduce de lleno en el fenómeno de la inmigración europea en Argentina ${ }^{41}$ La historia ificticia o en parte real ${ }^{42}$ de este francés (hijo de un "indiano") que había emigrado a América para repetir la aventura paterna y al que Valcárcel decía haber encontrado "en el mismo corazón del Chaco, hecho un semi-rey de una horda salvaje subordinada a su voluntad" termina por arrebatar la centralidad de la narración, con el detalle de su trayectoria a lo largo de trece años de estancia en Argentina, de los cuales llevaba diez en el Chaco. ${ }^{44}$

Desde el punto de vista histórico, la presencia de colonos franceses en la región es un hecho contrastable. Precisamente, a mediados del siglo XIX, entre los proyectos de colonización impulsados desde Paraguay destacan los acometidos con franceses en el sur chaqueño (Dalla-Corte y Vázquez Recalde, 2011: 123) y, en lo que respecta a Argentina, ya desde los años 1830 se hallaban afincados empresarios de ese origen, como el hacendado "vasco-francés" Pedro Luro, dedicado al negocio de tierras, animales, lanas y cueros ${ }^{45}$ y propietario de un saladero, que exportaba a Europa productos pecuarios (Fernández, 1999: 99). Es en este contexto en el que se podría explicar la existencia del extravagante Vernuil y de su boyante colonia, levantada con el trabajo de los tobas, dedicándose a la extracción de perlas (que mantenía a buen resguardo) y al negocio maderero, ambas actividades también realizadas por los indígenas, "remunerándolos con ciertos vicios" como los "licores" (Valcárcel, 1883: 27). Explotación laboral, expolio de recursos naturales y fomento del alcoholismo: una cruda realidad que vuelve obvios más comentarios. Independientemente de tratarse o no de un personaje inventado, los hechos relatados por Valcárcel, quitando la fabulosa "choza" del colono (el "mobiliario" de lujo y otros elementos de su vivienda), reflejan la realidad de las inversiones francesas en distintos ámbitos: agropecuario, comercio

\footnotetext{
${ }^{40}$ El nombre de "Gustavo" al lado del apellido "Vernuil" (ambos entrecomillados en el original) sólo aparece al final del relato (Valcárcel, 1883: 78); en una ocasión figura como "Verneuil", aunque debe advertirse que ambas formas existen en el idioma francés. Por lo demás, es frecuente la confusión del autor con respecto a nombres de pueblos indígenas o términos de la botánica o la zoología local; por citar unos ejemplos: "chiriguayo" por chiriguano; "angada" por jangada; "subirí" en lugar de surubí.

${ }^{41}$ Este solo aspecto merecería un trabajo más extenso, puesto que la obra aquí comentada aporta datos valiosos para conocer la mirada de dos europeos sobre la inmigración, a través del intercambio de opiniones entre el autor y Vernuil sobre la política migratoria argentina de esos años. Dado que Una Expedición al Chaco fue escrita una década después de concluida la participación de Valcárcel en ella, contiene referencias a la Ley de Inmigración y Colonización (1876) que llevaba ya siete años de vigencia y que resumía, a juicio del autor, el "pensamiento del gobierno" en cuanto a colonizar tierras indígenas con europeos en pro de la civilización, "su objeto principal" (Valcárcel, 1883: 54). Otro aspecto de interés que surge en la narración es el de la inmigración "escogida", también tratada en Castro Boedo (1873: 233 y ss).

${ }^{42}$ Las búsquedas realizadas sobre la existencia real de este personaje no han dado resultados.

${ }^{43}$ La manera en que Valcárcel se refiere a Vernuil suscita cierta -y casi inevitable- comparación con la aventura sudamericana de un compatriota suyo, Orélie-Antoine de Tounens, proclamado primer "rey" de la Araucanía por los mapuches en 1861.

${ }^{44} \mathrm{Su}$ "colonia" se hallaba situada en torno a la Laguna de las Perlas (Valcárcel, 1883: 31).

${ }^{45}$ De hecho, este francés de las selvas demostraba, en uno de los diálogos mantenidos con Valcárcel, su conocimiento del negocio de curtidos y de los grandes beneficios que reportaba (Valcárcel, 1883: 35).
} 
minorista y de exportación -sobre todo de lanas y algodón ${ }^{46}$ - y pequeñas industrias en Buenos Aires y provincias del Noroeste, del Litoral y Mendoza (Fernández, 1999: 20). De hecho, Vernuil se dedicaba a beneficiar la piel y el sebo del oso hormiguero, productos que luego enviaba a Corrientes, donde tenía su "corresponsal" (Valcárcel, 1883: 43). Empezando como mercachifle e intercambiando mercancías ${ }^{47}$ con grupos tobas en las fronteras de Corrientes, Vernuil había logrado aumentar su "reputación y ascendiente sobre la tribu" merced a las curaciones de enfermos de tifus con píldoras de quinina (Valcárcel, 1883: 27), prácticas que recuerdan los recursos misioneros para ganarse a los nativos compitiendo con sus chamanes. El mismo Vernuil aludía a sus "funciones de curandero" sujetas a los "preceptos de la ciencia" y "administrando" la homeopatía, "cuyo estuche no abandonaba jamás” (Valcárcel, 1883: 45).

Los éxitos de Vernuil, colono y civilizador de un grupo de indígenas del Chaco austral y constructor de un canal de desagüe para llevar las aguas de una laguna al río Bermejo, que consideraba "ciertamente mi obra, y en parte por ella adquirí la especie de corona salvaje que me ofrecieron estos pobres pueblos nómadas" (Valcárcel, 1883: 23). Los emprendimientos de Vernuil en el Chaco ocupan un lugar predominante en la narración, con la clara intención de exaltar los beneficios de la inmigración europea en la región; a partir de la "aparición" de ese personaje se alternan en el texto sus discursos, agasajos y otras actividades compartidas con Valcárcel durante la acampada del ejército en las cercanías de su colonia. Por lo demás, el mismo autor justificaría la reserva de espacio en la obra para "narrar [las] inesperadas impresiones" que le había causado este personaje (Valcárcel, 1883: 35). Por otra parte, la historia que de él se cuenta en Una Expedición al Chaco, presenta ciertas aproximaciones a la biografía del naturalista viajero Aimé Bonpland, convertido en el científico-héroe por las peripecias sufridas en el Paraguay, siendo probable que Valcárcel se inspirase en su figura para elaborar el personaje de Vernuil, quien precisaba: "El naturalista Bonpland, cuyos pasos he procurado seguir, llegó a establecer en el Paraguay una colonia parecida a la mía" (Valcárcel, 1883: 31).

Tras el encuentro de Vernuil y Valcárcel, en el relato asoma de inmediato cierta complicidad o si se quiere un sentimiento de hermandad europea, en virtud de la común pertenencia al viejo continente y más aun por la vecindad geográfica de sus respectivos países de origen. Lamentándose por llevar diez años sin hablar "la lengua de Corneille y de Molière”, Vernuil expresaba a Valcárcel: “... a tres mil leguas de la patria que nos vio nacer, los vecinos y los amigos son hermanos". Completando sus credenciales, agregaba: "Caballero oficial, soy el dueño de hecho de estos lugares, aunque extranjero en el país. Con toda confianza podéis aceptar la hospitalidad que os ofrezco en mi propio nombre y en el de la tribu que voluntariamente me obedece. Soy francés. Esta es la garantía de mis palabras" (Valcárcel, 1883: 20. Subrayado añadido). Esta era la propia opinión de Valcárcel, quien aparece rendido ante lo que consideraba superioridad francesa, materializada en Vernuil y su obra colonizadora, su

\footnotetext{
${ }^{46}$ Las exportaciones de estos productos se dirigían a las hilanderías del norte de Francia (Fernández, 1999: 19).

${ }^{47}$ A todas luces se trataba de un intercambio desigual, ya que a cambio de pieles y plumas daba a los indígenas "telas ínfimas, espejos, abalorios y otras baratijas" (Fernández, 1999: 27).
} 
capacidad de iniciativa, su laboriosidad e industria (Valcárcel, 1883: 23). El colono era presentado como el paladín de la inmigración europea y como la voz autorizada para proclamar sus beneficios y aportar sus recetas desde una posición paternalista: "Los indios, que hoy son un elemento de oposición, dejarían de serlo si con el espíritu que yo he desarrollado estas tolderías se establecieran colonias agrícolas para reducirlos", aunque "es disculpable [...] que los "jóvenes Estados no hayan hecho todo esto, porque es muy corto el periodo de su historia como naciones", abogando a la vez por la libertad individual y el fomento estatal de la colonización mediante una sentencia que reproducía el lema de los gobiernos liberales: "Los hombres de negocios no vendrán mientras no tengan primero paz y buena administración" (Valcárcel, 1883: 29). Sin embargo, el autor añadirá en el francés una nota de autocrítica a través de comentarios con reminiscencias de la idea del buen salvaje y que atenuaban la percepción negativa de los indígenas, "estos salvajes que, en el fondo, en sus manifestaciones y apetitos, tan poco se diferencian de los pueblos que se precian de no serlo". Palabras que tuvieron la réplica inmediata por parte de Valcárcel: "Me parece que os olvidáis que sois europeo y francés" (Valcárcel, 1883: 28).

La fantasiosa ${ }^{48}$ historia de Notaj/Diana, otro símbolo de las proezas de Vernuil en su condición de hombre blanco, europeo y civilizado, constituye uno de los aspectos más curiosos y sugerentes del relato. Presentada como su "ejemplar", la joven Notaj, nombre toba que significa "luz o día" -explicaba el autor- había sido adoptada por Vernuil a la edad de seis años, tras quedar huérfana a raíz de una epidemia de tifus que azotó a su comunidad. Esta Mademoiselle Notaj, "que será Mlle. Vernuil para el mundo", educada en la cultura europea, virtuosa en el piano y conocedora de obras clásicas de la literatura española (Pérez Galdós, Espronceda, Zorrilla) y francesa (H. Balzac, F. Soulié), era todo un portento de mujer que "reunía en su estética lo más bello de las distintas razas a que pertenecía, salvo [he aquí el matiz] algunos detalles de raza" (Valcárcel, 1883: 37).

La descripción física de la "india mestiza" no tiene desperdicio, haciendo hincapié en la mezcla étnica como causa de su atractivo: "A la pureza de las líneas célticas se unían el vigor y el fuego de las razas romanas, confundidos con los destellos de las pasiones africanas; conjunto indescriptible; mezcla informe de arrogancia e impetuosidad, de molicie y de poesía. Sus ademanes, de un gracioso americano incomparable, no eran la dejadez clásica de los pueblos tropicales, eran verdaderos compases musicales" (Valcárcel, 1883: 38). La exaltación del mestizaje --aspecto este sobre el que volveré más adelante-- no impedía que Valcárcel frunciese la nariz ante un rasgo negativo, que le venía a la joven por su lado indígena: "Un detalle verdaderamente típico denunciaba a la india Notaj. Ese olorcillo acre, que exhalan todos los individuos de su raza, imposible de cubrir aún con todos los perfumes reunidos". Ya en la lejanía, muchos años después de la experiencia chaqueña y sin el rastro perturbador de ese "olorcillo", la idealización de la mestiza no tendría fisuras, llegando a confesar Valcárcel que le sería necesario "recoger en cada una de entre mil mujeres un detalle,

\footnotetext{
${ }^{48}$ De hecho, en los prolegómenos de esta parte de relato, el mismo autor advierte al lector sobre lo "maravilloso" de lo que narrará a continuación (Valcárcel, 1883: 20).
} 
para poder formar con todos ellos reunidos una especie de falsificación de la mestiza" (Valcárcel, 1883: 38). La discursividad en torno a este personaje pone de manifiesto una visión positiva del mestizaje, en el convencimiento de que la sangre blanca mejoraba significativamente al individuo, desdibujando los vicios de la raza inferior ${ }^{49}$. El mestizaje de Diana, "dominando la raza española", tal como indicaba su padre adoptivo (Valcárcel, 1883: 37), servía al autor no sólo para reforzar su discurso sobre la superioridad de lo europeo y los alcances de su acción civilizadora sino también para hacer un elogio de lo español, en la línea de ensalzar su propio origen.

Por otra parte, en uno de los pasajes referidos a la hija de Vernuil, la narración conlleva la previsible cuña de los estereotipos sobre las funciones femeninas, acorde con el imaginario de la época: "Mientras nosotros [los hombres de las expediciones terrestre y fluvial] nos dirigíamos a las tolderías, la india mestiza disponía lo necesario para el almuerzo de sus huéspedes, alcanzando su educación este detalle del hogar, tan indispensable a la mujer" (Valcárcel, 1883: 43. Subrayado añadido). Como contrapartida, el autor ponía en boca de Diana una réplica en forma de alegato a favor de las indígenas, para responder a la generalizada opinión masculina sobre la banalidad como atributo femenino: “[...] según vuestros libros [dirigiéndose a Valcárcel], es una condición genuina de la mujer la frivolidad, es decir, de la mujer civilizada, pero en la india ya es otra cosa, Algo bueno habíamos de tener" (Valcárcel, 1883: 39). Esta apreciación no le impedía el disculparse por su mitad indígena, como se refleja en otro de los diálogos sostenidos con Valcárcel; en respuesta a lo que creyó ser una reprensión de este, la mestiza le expresaba: "[...] me olvidaba que mi origen es también salvaje" (Valcárcel, 1883: 59). Los ejemplos expuestos muestran en este personaje el reconocimiento o conciencia de una parte de su identidad, pero ya corregidos los elementos indeseables de su vertiente indígena, lo que justificaría la incorporación de otra faceta para completar su perfil, la de redentora de sus hermanos los indios: “¿Podré yo nunca olvidar mi origen y no hacer siquiera por mis hermanos, con mayor razón, lo que por mí se ha hecho?" (Valcárcel, 1883: 39).

Ante los encantos y virtudes de la mestiza, no era de extrañar que Valcárcel acabase rendido a sus pies, ante lo que ella no permaneció indiferente: "Diana, a mi presencia, experimentaba una emoción completamente desconocida en el terreno de la práctica". Interpuesta ya la trama sentimental en la narración y adquiriendo densidad con la aparición y disputa entre otros dos competidores (el oficial argentino Sandoval y Remini, el médico italiano) "para derrotarme y dejarme fuera de combate" (Valcárcel, 1883: 39), asistimos a la evolución de una historia rosa en medio de los asuntos relacionados con la expedición y los lucimientos discursivos de Vernuil y Valcárcel sobre el Chaco y su porvenir. El desenlace del triángulo amoroso (también utilizado por

\footnotetext{
${ }^{49}$ En el siglo XIX, la cuestión del mestizaje fue objeto de múltiples debates, tanto en Europa como en países de América, especialmente en aquellos en los que existía un claro predominio de la población negra, como era el caso de Cuba. En relación con estas discusiones cabe mencionar las ideas del pensador cubano Enrique José Varona, que defendía la mezcla entre razas en la convicción de que los elementos negativos de las consideradas "inferiores" se diluirían gracias a la aportación de las razas "superiores" (citado en García González y Naranjo Orovio, 1998: 278-279).
} 
el autor para marcar las diferencias de carácter entre ambos contendientes) se ofrece hacia el final del relato al decantarse Diana por Remini, con quien contraería matrimonio una vez instalados en Europa. El secreto anhelo de Valcárcel de concretar una relación sentimental con la joven, frustrado en gran medida por sus indecisiones, según daba a entender en su narración, daba paso a la confesión de sus sentimientos más íntimos y a un lamento final por la oportunidad perdida, "prometiéndome a mí mismo --decía-corregirme para lo sucesivo. Llegaba el caso, sin que me apercibiese de ello, y volvía a caer en los mismos errores" (Valcárcel, 1883: 77).

La narración se cierra con la sorpresiva noticia de la destrucción de la colonia levantada por Vernuil, cuando este y los suyos (Diana y Remini) se hallaban ya en Europa. Un final para el cual Valcárcel reservaba al francés y a su hija mestiza un gesto grandilocuente para rematar su heroicidad; inducida por su ya "anciano" padre, Diana lograría influir "sobre el corazón de su esposo", antes no muy convencido de tal acto de arrojo, para retornar al Chaco y poner nuevamente en pie las tolderías tobas. Con este motivo habían escrito a Valcárcel solicitándole su "auxilio" en función de sus "dotes y condiciones" (Valcárcel, 1883: 78), a lo que, evidentemente, no respondió nuestro autor, consagrado a afanes muy diferentes, como el de narrar viajes y reinventar/se en ellos.

\section{El mundo indígena}

En la suposición de que su obra habría de tener lectores mayoritariamente europeos, el autor de Una Expedición al Chaco justificaba la inclusión de referencias sobre las costumbres "propias de estos pueblos primitivos" (Valcárcel, 1883: 62), a cuyo fin echaba mano de los patrones discursivos acostumbrados, presentando la dicotomía entre "indios salvajes" o inciviles e "indios amigos", categoría esta última en la que, claro está, se hallaban los colonizados por el francés Vernuil. En contraste con las memorias de Castro Boedo y G. Araóz (y sin ánimo de hacer una comparación exhaustiva, que no cabría aquí), con una información detallada sobre los grupos indígenas de la región, Valcárcel se limitará a algunos datos etnográficos, que semejan ser recortes de las anotaciones misioneras sobre el Chaco y sus pueblos. En todo caso, al tratar diversos aspectos de la vida indígena, puede detectarse la funcionalidad del discurso a los efectos de cumplir con el objetivo último de la obra: demostrar la superioridad de la sociedad blanca, sobre todo europea, y su necesaria mediación para hacer de los nativos sujetos productivos. De paso, cuando los acontecimientos narrados lo permitían, Valcárcel introducirá sus elogios a la obra civilizadora de España en el pasado.

En el relato de las interacciones con diversos grupos indígenas pueden destacarse algunos contenidos de interés, como la acampada del ejército en la isla de Ñacurutú y el encuentro con "una numerosa familia de indios [tobas]", a quienes los expedicionarios se acercaron en son de amistad "porque teníamos hambre y sed de verlos", según confesaba Valcárcel (1883: 11); una clara manifestación de sus ansias por enfrentarse a lo que consideraría "emocionante", sin duda producto de imágenes prefabricadas sobre los habitantes de la región obtenidas en sus lecturas chaqueñas. 
Otro dato sugerente se halla en el diálogo del autor con el anciano cacique Fortunato ${ }^{50}$ --cuya comunidad no había vuelto a tener contacto con los blancos tras las guerras de la independencia, en las que habían combatido "en la causa de España"-- y en la pregunta por aquél formulada: “¿Y cómo está nuestro rey don Fernando VII?” (Valcárcel, 1883: 12), un detalle anecdótico introducido por Valcárcel en su narración; es probable que la ilustración referida a este episodio y añadida al texto, obedeciese al ánimo de incidir en el pasado hispánico y en una fidelidad monárquica que haría de estos tobas hombres menos salvajes. Por otro lado, la mencionada anécdota nos remite a esos diálogos insertos a la manera de los misioneros o expedicionarios en sus crónicas, recogiendo supuestamente las voces indígenas, cuando en realidad simbolizan la voz de quienes tenían el poder de la escritura ${ }^{51}$. Por lo demás, los viejos hábitos de la conquista se hacen presentes en los obsequios a los indios amigos, "con todo lo que pudimos, vaciando nuestras cantimploras, cargadas de ginebra" a cambio de charatas y pescado, en un trueque habitual por el que el civilizado fomentaba entre los indígenas lo que luego convertía en objeto de censura (la ebriedad). La edad del mencionado Fortunato, calculada en unos ochenta años, era vista por el autor como "un gran signo en cuanto a las condiciones climatológicas del país. Y esta verdad la confirmé más tarde, con otros más viejos y mejor conservados que [él]" (Valcárcel, 1883: 12), referencias estas que aparecen a menudo en los crónicas coloniales (de jesuitas, sobre todo) y que no esconden la fantasía de la longevidad de los chaqueños por sus hábitos de vida contrarios al sedentarismo, sin duda como reclamo dirigido al público europeo.

Con relación a las costumbres de los grupos indígenas del Chaco, los datos ofrecidos están referidos a los tobas, incluyendo aspectos como la autoridad de los caciques y los modos de hacer la guerra, sin faltar el comentario sobre las pinturas faciales "que les dan un aspecto horrible" (Valcárcel, 1883: 16). En cuanto a la cultura material el relato aporta unos escuetos datos sobre las armas, las bebidas consumidas, la vivienda y los vestidos, haciendo hincapié en los materiales de que estaban hechos y en su modo de fabricación, que el autor describía como "groseros" (Valcárcel, 1883: 11) con la intención de remarcar la falta de tecnología, lo que se aplicaba desde los tejidos hasta la "chicha" (Valcárcel, 1883: 16), frente a la calificación positiva que merecían los elementos producto de la "industria" del colono Vernuil y de los indígenas bajo sus órdenes. Claro está, sin olvidar la mención de lo "extremadamente sucios ${ }^{52}$ que eran estos últimos "a pesar de vivir casi constantemente en el agua" (ídem), en contraste con el oasis perfumado que simbolizaba la "choza" del francés (Valcárcel, 1883: 23).

Fuera de lo señalado, cabe incidir en una cuestión relevante, atendiendo a los fines con los que Valcárcel elaboró su escrito. Conforme a los intereses gubernamentales que subyacían en los planes oficiales de fomento a la colonización de los territorios indígenas, el salvajismo era una condición propia de los grupos no asimilados y por ende

\footnotetext{
${ }^{50}$ Castro Boedo (1873) también hace referencia a este "capitanejo", al que describía como "cristiano, fugitivo entre los indios" (p. 123).

${ }^{51}$ Sobre esos intercambios verbales en las "zonas de contacto" (Prat, 2011), véase Vitar (2014).

${ }^{52} \mathrm{La}$ "suciedad" formaba parte de los rasgos que distinguían a los pueblos "salvajes" desde la óptica occidental (Rodríguez Mir, 2006: 239).
} 
improductivos, criterio que sustentó las estrategias de dominación puestas en marcha en la fase de construcción del Estado nación y la categorización de los indígenas como civilizados o incivilizados. Sin embargo, esta postura abreva en el pensamiento ilustrado subyacente en la política de la Corona española a fines del siglo XVIII con relación a los "indios bravos" de las fronteras imperiales. Bajo el reformismo borbónico, la aplicación de los principios del Nuevo sistema de gobierno económico para la América (José del Campillo, 1789 $)^{53}$, se tradujo en un giro significativo en la política a seguir con los bárbaros fronterizos, cuya sujeción y asimilación al sistema colonial debía hacerse "a través del comercio más que por medio de la conquista física o espiritual" (como antes se había perseguido con la guerra y el régimen reduccional), prodigándoles un "buen trato" con el propósito de convertirlos en "productores y consumidores" (Weber, 1998: 152-154), como también preconizaba Valcárcel en su obra. Unido a esto, otra faceta de interés que presenta la narración es el fenómeno del mestizaje, materializado en la figura de Diana/Notaj, que simbolizaría el puente o vía para la asimilación pretendida por el Estado en su proyecto homogeneizador para consolidar la nación. En este plano, ya en el marco de la política reformista de los Borbones se había formulado la vía de la asimilación frente a la tradicional segregación racial establecida por la legislación indiana (las Repúblicas de Indios) y que había tenido su más clara expresión en las reducciones jesuíticas en tanto "reservorios de pureza étnica" (Wilde, 1999: 626). Como señala este autor, la razón ilustrada y las ideas que "hacían del trabajo, el comercio y la ciencia, palabras resonantes del discurso racionalista de la reforma", dieron paso al replanteamiento de la política indígena, fundamentado "en los principios centrales de una prédica universalista que poco a poco resquebrajaba los valores tradicionales. Al ser este un modelo universal era pasible de ser asimilado por y contagiado a quienes no lo poseían" (Wilde, 1999:632).

En la visión utilitarista del territorio bajo el influjo del capitalismo expansionista, el "primitivismo" de los chaqueños tenía una de sus razones de ser en el desaprovechamiento productivo del entorno, según los argumentos expuestos en la fuente aquí analizada. El Chaco poseía abundantes recursos, pero "el hombre primitivo no conoce el valor de lo que lo rodea"; tal riqueza se ofrecía "para poner a su servicio hombres, animales y selvas, porque son esclavos del saber y de la inteligencia" (Valcárcel, 1883: 9). Al margen de la lógica capitalista de explotación y acumulación de excedentes, las actividades desarrolladas por los pueblos chaqueños no contaban y tampoco quienes las desarrollaban: eran invisibilizados. El Chaco Gualamba, expresaba Valcárcel, una región "varias veces explorada, permanece aun olvidada a la actividad del hombre" (Valcárcel, 1883: 9ídem). En medio de estas declaraciones, no deja de resultar sorprendente el concepto de "ciudadanía" aplicado a los indígenas; tal derecho era alcanzable mediante la práctica de un "sistema dulce" para reducirlos y hacerlos ciudadanos con deberes y derechos, "tarea ineludible bajo el punto de la civilización, del honor de América y de la repoblación, fuentes poderosas de su riqueza" para salvar el honor de América. Tal era el objetivo del gobierno: convertir a los nómadas del Chaco

\footnotetext{
${ }^{53}$ Sobre la polémica surgida en torno a la autoría de este texto, que constituyó "un plan maestro para el
} desarrollo económico de las colonias", véase Weber, 1998: 154-155. 
en "ciudadanos consumidores y productores" (Valcárcel, 1883: 19, 54. Cursiva en el original).

Para civilizar a los indígenas tampoco eran desechables otros recursos: en opinión de Valcárcel, había que poner ante sus ojos artefactos (un instrumento musical y una cámara fotográfica, por ejemplo) y desplegar acciones que demostrasen la superioridad de los civilizados sobre ellos: "Era necesario sacar partido del encuentro, anonadándolos con los poderosos elementos del hombre civilizado, para imponernos y hacernos respetar" y tanto valían, en este sentido, un concierto con acordeón como un "llamado a las armas" de la tropa para enseñarles la disciplina militar (Valcárcel, 1883: 19). La redención de los pueblos chaqueños, vendría a través de la obra civilizadora, no para volverlos cristianos sino "pueblos productores".

Sin embargo, frente a la alteridad femenina en su triple vertiente étnico-social y de género, permanecen enquistadas las posturas tradicionales. Como es previsible en un autor de la época, las mujeres no aparecen con nombre propio: tanto las que iban con la tropa de Valcárcel, con la labor de curar heridos entre otras tareas femeninas (lavado, cocina, recogida de leña y agua para el campamento, etc.), que ni siquiera se mencionan en Una Expedición al Chaco. Sobre las indígenas, englobadas bajo el término de "chusma" junto a los niños, se repiten los clichés acostumbrados, siguiendo las pautas descriptivas de las crónicas coloniales (y no sólo de las jesuíticas), a su vez heredadas por los escritores de la etapa criolla y, claro está, plasmadas en el texto de Valcárcel: "Las mujeres son un ser abyecto para ellos, y hacen los trabajos más rudos, y ellas miran al hombre como su dueño y señor" (Valcárcel, 1883: 16). Una imagen de fuerte contraste con la que el autor reservaba para Diana, la mestiza idealizada hasta el paroxismo.

\section{Notas finales}

La fuente aquí comentada forma parte de la abundante narrativa producida en el siglo XIX como resultado de los viajes de exploración realizados a regiones que se hallaban fuera del control estatal y habitadas por pueblos bárbaros, como era el caso del Chaco. En el marco del proyecto de consolidación nacional puesto en marcha por la elite gobernante, la conquista y apropiación territorial así como la asimilación de la población indígena en nombre de la modernidad, tuvo en toda esa masa textual un singular vehículo de legitimación. Una Expedición al Chaco, de César Valcárcel, no fue la excepción. Por otra parte, en consonancia con aquel proyecto político para los territorios que había que redimir de la barbarie y en plena fase de expansión capitalista, se impone una visión utilitarista de la región, cuya naturaleza y recursos son resaltados de modo recurrente, bajo la perspectiva de convertirlo en un espacio productivo acorde con las demandas del mercado internacional. Por lo demás, y con vistas a estos propósitos, el texto contiene un acopio de argumentos a favor de la inmigración europea y su instalación en la zona, como la vía idónea para civilizar a sus primitivos habitantes y explotar sus riquezas. 
De modo paralelo, en la narrativa valcarceliana no menor consideración merecen los discursos sobre la identidad. Con el trasfondo de un universo pluriétnico, el propio autor y el colono Vernuil --uno de los personajes ficticios introducidos en el relato-definen sus rasgos identitarios que obran, a su vez, como elementos justificadores de la superioridad europea y de su necesaria intervención para modernizar a los primitivos, convirtiéndolos en productores y consumidores, dos atributos definidores del indígena ideal. Si bien frente al colono Vernuil e incluso "utilizando" a este personaje, Valcárcel exalta las virtudes características de la españolidad, es sobre todo en la figura del francés donde puede hallarse la plena legitimación del argumento de la superioridad del europeo, capaz de sacar al Chaco de su postración e improductividad. En todo este entramado, la presencia del mestizaje es otro aspecto digno de interés, en tanto la figura de Notaj/Diana, la mestiza (de padre español y madre toba) adoptada por el colono Vernuil aparece como proyección de su gran "obra" civilizadora, acometida entre un grupos de tobas. Los atributos positivos que adornan a ese personaje femenino, que Valcárcel adjudica a su ascendencia española por el lado paterno y a la esmerada crianza y educación recibida de su padre adoptivo, más que validar la mezcla racial tendría la intencionalidad de exaltar, en esa síntesis de virtuosidad y laboriosidad hispano-francesa, la conveniencia del aporte europeo en la conformación identitaria de una nación en ciernes.

Por último, como narrativa de viajes, la obra de Valcárcel ofrece interesantes perspectivas de análisis, en parte sugeridas a lo largo de estas páginas, quedando para futuros trabajos la profundización de los aspectos abordados así como otros que no han sido abordados aquí. Una Expedición al Chaco es de difícil clasificación como género narrativo, constituyendo un auténtico collage en el que se entremezclan los tópicos de la literatura de viajes del romanticismo, de los informes de comisiones oficiales y de una obra apologética sobre las bondades del proyecto gubernamental de modernización del Chaco. Sin obviar el tipo de información inherente a las crónicas sobre expediciones geográficas y satisfacer con ello la deuda de gratitud que decía haber contraído, el propósito de Valcárcel fue, al fin y al cabo, elaborar un relato para el gran público, europeo en especial, reduciendo a lo indispensable el caudal descriptivo que caracterizaba las "etnografías" coloniales o las obras contemporáneas sobre el Chaco, para dar paso a la propaganda a favor de la inmigración europea y al ensalzamiento de sus beneficios para el país. Sumado a ello, la introducción de elementos de ficción, a los que no logró sustraerse el autor por su "exaltada" imaginación, dan como resultado una obra que se queda a medio camino entre un informe al Gobierno argentino y la pretensión de ser una especie de "novela" sobre la expedición, con el ingrediente de una historia amorosa. Escrito este texto por el autor tras su retorno a España, y más aun, atendiendo al hecho de que primero fue publicando su contenido por partes, cuántas recreaciones de su experiencia chaqueña no habría en la versión final (el relato de 1883), en una última re-invención de sí mismo y de los otros. 


\section{Referencias bibliográficas}

Fuentes impresas

Aráoz, G. 1886. Navegación del Río Bermejo y viajes al Gran Chaco. Buenos Aires: Imprenta Europea y Taller en Grabados en Madera.

Castro Boedo, E. 1873. Estudios sobre la navegación del Bermejo y colonización del Chaco practicados por el doctor... en 1872. Buenos Aires: Imprenta y Fundición de Tipos de la Sociedad Anónima.

Rams y Rubert, E. y Riestra, N. de la. 1860. Prospecto. Empresa de Navegación de los Ríos Salado y Bermejo. Buenos Aires: Imprenta del Orden. Disponible en http:// liberalism-in-americas.org/369/ [Consulta: 15/05/2016]

Valcárcel, C. 1882. Impresiones de viaje desde la Península hasta Buenos Aires: formando el conjunto una completa guía del viajero describiendo la posición geográfica, histórica... Madrid: Imprenta de Enrique Rubiños.

Valcárcel, C. 1883. Viajes por la República Argentina. Una expedición al Chaco. Edición ilustrada con grabados. Madrid: Imprenta y Librería de J. Gaspar, Editor.

Valcárcel, C. 1888. Del natural: novela de costumbres contemporáneas. Habana, Imprenta de "La Universal" de Ruiz y Hermano.

Obras de consulta

Arce Birbueth, E. et al. 2003. Estrategias de sobrevivencia entre los tapietés del Gran Chaco. La Paz: Dirección de Investigación Científica y Técnica.

Areces, N. R. 2008. "Imágenes de una frontera en el corazón de América del Sur. De las Partidas Demarcadoras hispanoportuguesas a las vísperas de la Guerra del Paraguay”. En: S. Fernández y M. Pierini (Eds.), Derroteros del viaje en la cultura: mito, historia y discurso. Rosario: Prohistoria Ediciones. pp. 165-182.

Augé, M. 2006. "El viaje inmóvil”. En: M. Lucena Giraldo y Juan Pimentel (eds.). Diez estudios sobre literatura de viajes. Madrid: Consejo Superior de Investigaciones Científicas. pp. 11-15.

Borrero Barrera, M. J. 2000. "El tipo textual del naufragio: discurso figurativo, discurso verídico y discurso real". En: I. de Riquer, E. Losada Soler y H. González Fernández (eds. lit.). Professor Basilio Losada: ensinar a pensar con liberdade e risco (199-205). Barcelona: Universitat de Barcelona.

Cecchetto, G. 2013. “Civilización, progreso e imaginación geográfica. El informe de la Comisión Exploradora del Chaco (1876)". Revista Intersticios de la política y la cultura, Vol. 2 (4), Córdoba, Grupo de Filosofía Latinoamericana, Universidad Nacional de Córdoba, pp. 25-41.

Cecchetto, G. 2015. "Explorar, imaginar y relatar el territorio: viajes y tecnologías de poder en la producción y legitimación de saberes geográficos en la Universidad Nacional de Córdoba, 1876-1882". XIII Coloquio Internacional de Geocrítica: El control del espacio y los espacios de control. Barcelona, 5-10 de mayo de 2014. Barcelona: Universitat de Barcelona/Geocrítica. 
Corbera Millán, M. 2014. "Ciencia, naturaleza y paisaje en Alexander von Humboldt". Boletín de la Asociación de Geógrafos Españoles, 64, pp. 37-64.

Cruz Casado,A. 2003. "El mito romántico del bandolero andaluz (Los viajeros románticos y José María El tempranillo)”. Alicante: Biblioteca Virtual Miguel de Cervantes. Disponible en: http://www.cervantesvirtual.com/obra-visor/el-mito-romnticodel-bandolero-andaluz-los-viajeros-romnticos-y-jos-mara-el-tempranillo-0/html/ ffe47ae0-82b1-11df-acc7-002185ce6064_4.html\#I_1_[Consulta: 13/05/2016]

Dalla-Corte, G. y Vázquez Recalde, F. 2011. La conquista y ocupación de la frontera del Chaco entre Argentina y Paraguay. Los indígenas tobas y pilagás y el mundo religioso en la Misión Tacaaglé del Río Pilcomayo (1900-1950). Barcelona: Universitat de Barcelona.

Dávilo, B. y Gotta, C. (Comp.) 2000. Narrativas del desierto. Geografias de la alteridad. Rosario: UNR Editora.

De Cristóforis, N. A. 2010. Extranjeros, nativos y ciudadanos en las miradas de los viajeros de mediados del siglo XIX. En: Fernández, Sandra R. y Reguera Andrea (comp.). Imágenes en plural. Miradas, relatos y representaciones sobre la problemática del viaje y los viajeros. Rosario: Prohistoria Ediciones. pp. 111-131.

Depestre Catony, L. 2009. "Aniceto Valdivia, el Conde Kostia de la literatura cubana”. Cubaliteraria. Portal de Literatura Cubana. Disponible en: http://www. cubaliteraria.com/articulo.php?idarticulo $=7979 \&$ idseccion $=35 . \quad[$ Consulta: 10/05/2016]

Fernández, A. E. y Moya, José C. (Eds.) 1999. La inmigración española en la Argentina. Buenos Aires: Biblos.

Fernández, María Inés 1999. Las inversiones francesas en Argentina, 1880-1920. Buenos Aires: Editorial Biblos / Fundación Simón Rodríguez.

García González, A. y Naranjo Orovio, C. 1998. “Antropología, 'raza’ y población en Cuba en el último cuarto del siglo XIX”. Anuario de Estudios Americanos, Vol. LV, Sevilla, Escuela de Estudios Hispanoamericanos, pp. 267-289.

Gordillo, G. 2015. "Barcos varados en el monte. Restos del progreso en un río fantasma”. Runa, 36-2, pp. 25-55.

Huergo, Luis A. 1902. Navegación interna en la República Argentina. Canal de Córdoba al río Paraná. Buenos Aires: Imprenta de la "Revista Técnica". Disponible en: https://archive.org/stream/navegacinintern00huergoog\#page/n7/mode/2up [Consulta: 03/04/2016]

Lagos, M. y Santamaría, D. 2008. "Barcos en la selva. El Bermejo: un modelo frustrado de comunicación e intercambio”. En: 3as Jornadas de Historia de la Patagonia, San Carlos de Bariloche, 6-8 de noviembre de 2008 (1-14). Disponible en: www. hechohistorico.com.ar/Trabajos/...\%202008/Lagos-Santamaria.pdf [Consulta: 23/04/2016]

Lois, C. 1999. "La invención del desierto chaqueño. Una aproximación a las formas de apropiación simbólica de los territorios del Chaco en los tiempos de formación y consolidación del Estado nación argentino". Scripta Nova. Revista Electrónica de Geografia y Ciencias Sociale, 38. Barcelona, Universidad de Barcelona. Disponible en: http://www.ub.edu/geocrit/sn-38.htm [Consulta: 10/04/2016] 
Navarro Floria, P. 2007. Paisajes del progreso. La resignificación de la Patagonia Norte, 1880-1916. Neuquén: Educo/CEP.

Núñez Seixas, X. 2001. La Galicia austral. La inmigración gallega en la Argentina. Buenos Aires: Biblos.

Oro, A. de y Rodríguez, J. 2008. "Sobre fuentes históricas y relatos de viaje”. En: S. Fernández y M. Pierini (Eds.), Derroteros del viaje en la cultura: mito, historia y discurso. Rosario: Prohistoria Ediciones. pp. 21-32.

Ortega Román, J. J. 2006. "La descripción en el relato de viajes: los tópicos". Revista de Filología Románica, anejo IV, Madrid, Universidad Complutense de Madrid, pp. 207-232.

Pérez, A. 2006. "De cazadores de cabezas a cazadores de sueños: la Amazonía en la literatura de viajes". En: M. Lucena Giraldo y Juan Pimentel (eds.). Diez estudios sobre literatura de viajes. Madrid: Consejo Superior de Investigaciones Científicas. pp. 195-228.

Pratt, M. L. 2011. Ojos imperiales. Literatura de viajes y transculturación. Buenos Aires: FCE.

Real Academia de Bellas Artes de San Fernando. Catálogo de Artistas del siglo XIX. Disponible enhttp://www.realacademiabellasartessanfernando.com/assets/docs/ laminas/laminas_sxix_artistas.pdf [Consulta: 23/04/2016]

Reguera, A. 2008. "América a través de sus viajes. El expansionismo como empresa de civilización. Los relatos de viajeros en el siglo XIX”. En: Sandra Fernández, Patricio Geli y Margarita Pierini (eds). Derroteros del viaje en la cultura: mito, historia y discurso. Rosario: Prohistoria Ediciones. pp. 195-203.

Rodríguez Mir, J. 2006. "Las fronteras en el imperio de la civilización. Génesis de las categorías étnicas en América Latina”. Revista de Antropología Experimental, 6, Jaén, Universidad de Jaén, pp. 235-250.

Schniebs, A. 2008. "El crucero del amor: pasión, viaje y escritura en la didáctica erótica de Ovidio". En: Sandra Fernández, Patricio Geli y Margarita Pierini (eds). Derroteros del viaje en la cultura: mito, historia y discurso. Rosario: Prohistoria Ediciones. pp. 119-130.

Vitar, B. 2010. "Francia y Centroeuropa en la mirada de un científico español: los 'viajes minero-metalúrgicos’ de Lorenzo Gómez Pardo”. En: Sandra R. Fernández y Andrea Reguera (comp.). Imágenes en plural. Miradas, relatos y representaciones sobre la problemática del viaje y los viajeros. Rosario: Prohistoria Ediciones. pp. 93-109.

Vitar, B. 2014. "Un testimonio a múltiples voces. La rendición de los malbalaes según la Descripción Corográfica del Gran Chaco Gualamba, de Pedro Lozano". Corpus. Archivos virtuales de la alteridad americana, Vol. 4-1 [En línea] URL: http:// corpusarchivos.revues.org/656.

Weber, D. 1998. "Borbones y bárbaros, centro y periferia en la reformulación de la política de España hacia los indígenas no sometidos". Anuario IEHS, 13. Tandil, Universidad Nacional del Centro, pp. 147-171. 
Wilde, G. 1999. "¿Segregación o asimilación? La política indiana en América meridional a fines del período colonial". Revista de Indias, Madrid, Consejo Superior de Investigaciones Científicas, pp. 619-644.

Zusman, P. 2000. "Desierto, civilización y progreso. La Geografía del Gran Chaco y el proyecto político territorial de la formación del Estado Argentino". Ería, 51, Oviedo, Universidad de Oviedo, pp. 60-67. 